\title{
Oxygen Isotope Evidence for Large-Scale Interaction between Meteoric Ground Waters and Tertiary Granodiorite Intrusions, Western Cascade Range, Oregon ${ }^{1}$
}

\author{
Hugh P. TAYLOR, JR. \\ Division of Geological and Planetary Sciences \\ California Institute of Technology, Pasadena 91109
}

\begin{abstract}
${ }^{18} \mathrm{O}$ data have been obtained on 7 of the 17 intrusive centers of diorite and granodiorite (Miocene?) that lie along a $N-S$ belt about $50 \mathrm{~km}$ west of the High Cascades. Whole-rock $\delta$ values (per mil relative to SMOW) in the intrusive stocks are: +2.3 to +4.9 (South Umpqua River), -0.7 to +3.8 (Bohemia mining district), +4.3 to +4.6 (Vida stock), -0.2 to +5.5 (Nimrod stock), -1.7 to +0.5 (Detroit stock), -2.1 to +0.7 (Laurel Hill stock, Mt. Hood area), and +2.9 to +5.5 (Shellrock, Columbia River). The volcanic country rocks (mainly andesites) in the vicinity of the intrusions are also depleted in ${ }^{18} \mathrm{O}$, with $\delta=-5.6$ to +4.5 . The rocks collected more than 3 stock diameters from an intrusive contact have 'normal' $\delta$ values of +5.8 to +8.2 . Approximately $1200 \mathrm{~km}^{2}$ ( $8 \%$ of the area of the Western Cascades) thus appears to be underlain by propylitically altered igneous rocks that have suffered an average ${ }^{18} \mathrm{O}$ depletion of about 5 to 7 per mil. These $\delta^{18} \mathrm{O}$ effects are similar to those previously discovered in the Tertiary intrusive centers of western Scotland and the San Juan Mountains, Colorado. They are typically associated with (1) pervasive epidote and chlorite alteration; (2) 'turbid' feldspars; (3) granophyric textures and miarolitic cavities; and (4) young, jointed, flat-lying, volcanic country rocks that are known to be highly permeable to ground-water flow. Convective circulation of heated ground waters in the vicinity of the stocks must have occurred throughout a large part of their crystallization and cooling history. The amounts of $\mathrm{H}_{2} \mathrm{O}$ involved are estimated to be about equal in volume to that of the exchanged rock. Hence, much so-called 'deuteric' alteration of igneous rocks is probably caused by such meteoric-hydrothermal waters rather than by $\mathrm{H}_{2} \mathrm{O}$ released during magmatic crystallization.
\end{abstract}

\section{INTRODUCTION}

Several recent oxygen isotope studies have demonstrated that certain epizonal igneous intrusions (i.e., those emplaced at relatively shallow depths in the earth's crust) have interacted strongly with meteoric ground waters during their crystallization and cooling history [Taylor, 1968; Taylor and Forester, 1971]. The effects of such interactions are readily discerned by means of ${ }^{18} \mathrm{O} /{ }^{16} \mathrm{O}$ analyses, because 'normal' igneous rocks throughout the world have ${ }^{18} \mathrm{O} /{ }^{16} \mathrm{O}$ values that are uniformly 6 to 10 per mil heavier than mean ocean water, whereas meteoric ground waters are typically 5 to 10 per mil lighter than ocean water. Igneous rocks that have exchanged with large quantities of heated ground waters

1 Contribution 1996 of the Division of Geological and Planetary Sciences, California Institute of Technology, Pasadena.

Copyright (C) 1971 by the American Geophysical Union. at high temperatures thus can have their ${ }^{18} \mathrm{O} /{ }^{16} \mathrm{O}$ ratios lowered by as much as 10 to 15 per mil.

In the Skaergaard intrusion, east Greenland, and at Skye, Mull, and Ardnamurchan in the Scottish Hebrides, where the isotopic phenomena were first observed, the igneous rocks that are abnormally low in ${ }^{18} \mathrm{O}$ characteristically display the following geological, petrological, and isotopic features: (1) The intrusions are emplaced into young, highly jointed, flat-lying plateau lavas that are very permeable to ground-water movement. (2) In a given rock, the feldspars are commonly isotopically exchanged to a greater degree than the other coexisting minerals, and the feldspars very commonly show a 'clouding' or turbidity (particularly the alkali feldspars). (3) The primary igneous pyroxenes and olivines are almost invariably partially altered to uralitic amphibole, chlorite, Fe-Ti oxides, and/or epidote; locally, this process has gone to completion and only pseudomorphs of the primary igneous minerals remain. (4) Granophyric (micrographic) 
intergrowths of turbid alkali feldspar and quartz are ubiquitous. (5) Miarolitic cavities are locally present in the intrusives, and veins filled with quartz, alkali feldspar, epidote, chlorite, or sulfides are very common in both the intrusives and the surrounding country rocks.

A good case can be made that these characteristics are wholly or in large part a result of interactions between the rocks and heated meteoric ground waters set into convective movement by the heat emanating from the igneous intrusions [Taylor, 1968; Taylor and Epstein, 1968; Taylor and Forester, 1971]. Ground waters are heated in the vicinity of the intrusion, and because of lowered density they rise; they are replaced by denser, cooler waters that migrate radially inward toward the intrusive heat source. These heated, low-18 $\mathrm{O}$, meteoric-hydrothermal waters exchange oxygen with the minerals in the intrusion and in the surrounding country rocks. If enough low-18 $\mathrm{O}$ water moves through the rocks, the ${ }^{18} \mathrm{O} /{ }^{10} \mathrm{O}$ ratios of the rocks are markedly lowered.

A very useful test of the above hypothesis would be (1) to pick an isotopically unknown area in which the aforementioned geological and petrological features are known to be present; (2) to predict that the intrusions in such an area should show the low-18 $\mathrm{O}$ effects typically associated with hydrothermal ground-water interaction; and (3) then to isotopically analyze samples from such an area to check this prediction.

Buddington and Callaghan [1936] have described the petrology and geology of a series of dioritic to granodioritic intrusive bodies in the Western Cascade Range, Oregon, and all the features outlined above are present at least locally in these intrusions, according to their descriptions. These stocks all are intruded into relatively flat-lying Tertiary volcanic rocks, principally basalts and andesites. Their exact age of emplacement is unknown, but they are thought to have been intruded in the Miocene [Buddington and Callaghan, 1936; Peck et al., 1964]. The intrusions are now exposed as a result of erosion by the westward-flowing rivers of the Cascades. The stocks tend to be arranged in clusters within a narrow N-S belt that lies about $50-60 \mathrm{~km}$ west of the Pleistocene and Recent volcanoes of the High Cascades; this belt extends across the entire width of Oregon (Figure 1). The intrusive bodies range in greatest

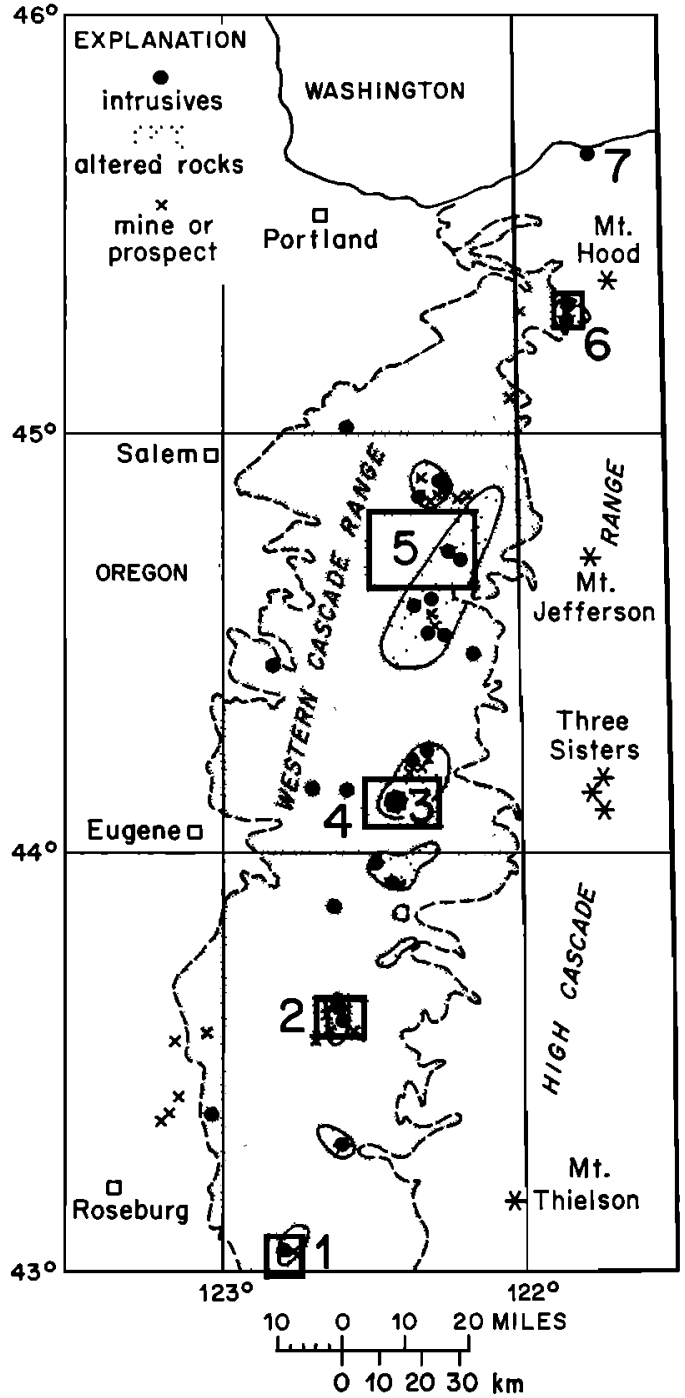

Fig. 1. Map of part of western Oregon. The Tertiary volcanic rocks of the Western Cascade Range are indicated by the dark stippled pattern; also shown are the occurrences of Tertiary diorites and granodiorites, as well as the areas of propylitic alteration and mineralization that are commonly associated with these medium-grained igneous rocks [modified after Peck et al., 1964]. The numbers indicate the various localities studied in this work: (1) South Umpqua River (Figure 3); (2) Bohemia Mining District (Figure 4); (3) Nimrod stock (Figure 5); (4) Vida stock; (5) Detroit Reservoir (Figure 6); (6) Laurel Hill stock (Figure 7); (7) Shell Rock intrusion, Columbia River. 
dimension from a few meters to $4 \mathrm{~km}$, and although most are augite diorites or quartz diorite porphyries, some of the larger stocks are principally granodiorite or quartz monzonite.

The Western Cascades intrusive belt thus appeared to have all the characteristics necessary to make it a worthwhile area on which to do an oxygen isotope study. It was hoped, first of all, that low- ${ }^{-18} \mathrm{O}$ rocks would be found, and second, that the distribution of ${ }^{18} \mathrm{O} /{ }^{16} \mathrm{O}$ ratios would provide useful information on the nature of the postulated interactions between intrusions and the waters present in the adjacent country rocks. In particular, it was hoped that the ${ }^{18} \mathrm{O}$ data could be related to contact metamorphism, regional hydrothermal alteration, and the formation of associated ore deposits. There are no large mines in these areas, but every one of the intrusive localities has some associated mineralization, notably the Bohemia mining district (Figure 1), from which about $\$ 1,000,000$ worth of gold was removed from 1870 to 1940 .

\section{Analytical Results}

The ${ }^{18} \mathrm{O} /{ }^{16} \mathrm{O}$ analyses obtained in this study are all plotted on generalized geologic maps presented below, and the data are also shown graphically in Figure 2. They are given as $\delta$, defined as

$$
\delta=\left(\frac{R_{\text {ample }}}{R_{\text {standerd }}}-1\right) 1000
$$

where $R={ }^{18} \mathrm{O} /{ }^{16} \mathrm{O}$. The standard is SMOW, standard mean ocean water. Many of the ${ }^{18} \mathrm{O} /{ }^{10} \mathrm{O}$ values were determined in replicate, and they should all be accurate to \pm 0.2 per mil. On the figures, the numbers in italics are analyses of volcanic country rocks; the other numbers represent analyses of the intrusive bodies. Most analyses are of whole-rock samples, which represent 25-mg splits from a 10- to 15-gram sample of a hand specimen that had been crushed and ground to pass 100 mesh screen. Mineral separates were prepared for analysis by conventional techniques, except that all quartz separates were given a final treatment with $\mathrm{HF}$ to remove any traces of mineral impurities (principally feldspar). Oxygen isotopic fractionations among coexisting minerals are conveniently reported as $\Delta_{A B}$, defined as $1000 \ln \alpha_{A B}$, where $\alpha_{A B}$ is ${ }^{18} \mathrm{O} /{ }^{16} \mathrm{O}$ in mineral $A$ divided by ${ }^{18} \mathrm{O} /{ }^{16} \mathrm{O}$ in mineral $B$. To a very close approximation, $\Delta_{A B} \approx \delta_{A}-\delta_{B}$.
Note that fresh, unaltered basalts and andesites throughout the world typically have very uniform $\delta^{18} 0$ values of +5.5 to +6.5 . If they have undergone some weathering or low-temperature $\left(<100^{\circ} \mathrm{C}\right)$ hydrous alteration, they will usually have slightly higher $\delta$ values; also, plutonic granitic rocks generally have $\delta^{18} \mathrm{O}=$ +7.0 to +9.5 [Taylor, 1968]. Therefore, any igneous rock (intrusive or volcanic) analyzed in the present research that has a $\delta^{18} 0$ less than +5.5 is immediately suspected of having undergone hydrothermal exchange with heated low- ${ }^{18} \mathrm{O}$ meteoric waters. Such phenomena cannot be produced by hydrothermal exchange with primary magmatic ground waters, because such waters have a relatively well-defined $\delta^{18} \mathrm{O}$ of about +6.0 to +8.5 [Taylor, 1967].

As is shown in Figure 2, the mid-Tertiary intrusive igneous rocks and volcanic country rocks from the Western Cascades show pronounced differences in $\delta^{18} \mathrm{O}$ as compared with the fresh volcanic rocks and a single intrusive body (the Husband) from the younger High Cascades volcanoes. The latter have perfectly 'normal' $\delta^{18} \mathrm{O}$ values, and arguments will be presented below that, before hydrothermal alter-

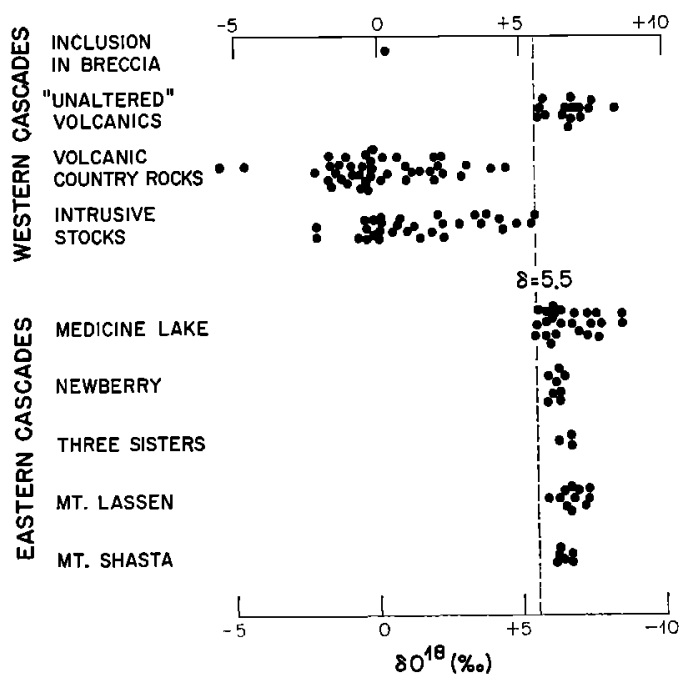

Fig. 2. Comparison of whole-rock $\delta^{18} \mathrm{O}$ values of Pleistocene and Recent volcanic rocks of the Eastern Cascades [Taylor, 1968; H. P. Taylor and I. Carmichael, unpublished data] with data on Tertiary igneous rocks of the Western Cascades. The inclusion in breccia $(\delta=+0.3)$ is a diorite fragment from an igneous breccia dike in the SW $1 / 4$ of sec. 32, T. 16S., R. 5E., $15 \mathrm{~km}$ due $\mathrm{E}$ of Nimrod. 
ation, the igneous rocks of the Western Cascades originally had 'normal' $\delta^{1 \mathrm{~B}} \mathrm{O}$ values as well. The whole-rock $\delta^{18} \mathrm{O}$ value of a sample of olivine microdiorite, representative of the north plug of the Husband, a 300-meter-wide body in the Three Sisters area, is $+\mathbf{6 . 2}$. This normal $\delta^{18} \mathrm{O}$ value is in keeping with the fact that this small Pleistocene stock was evidently emplaced at very shallow depths and has apparently not suffered any hydrothermal alteration [Williams, 1944].

\section{Discussion of Individdal Localities}

South Umpqua River. The southernmost area studied is on the South Umpqua River (Figure 1). The general geology of the area and the isotopic results are shown in Figure 3. The section of volcanic country rocks in this area is relatively thin, probably less than 1000 meters thick; these are Eocene andesites of the Colestin formation, which unconformably overlie the pre-Tertiary basement complex [Peck et al., 1964].

Two very small, elongate intrusive bodies of diorite porphyry were sampled. The westernmost body is apparently depleted in ${ }^{18} \mathrm{O}$ by only a small amount $(\delta=+4.9)$, but the easternmost intrusive has $\delta=+2.3$ and must have been depleted in ${ }^{19} \mathrm{O}$ by about 4 per mil or more. Two samples of the volcanic country rocks, one within a few meters of the intrusive contact $(\delta=+2.0)$ and the other an inclusion in the diorite porphyry $(\delta=+3.1)$, have also been depleted in ${ }^{18} \mathrm{O}$ relative to the country rocks well away from these small intrusives; two samples collected more than $1 \mathrm{~km}$ away have normal $\delta^{18} O$ values of +6.7 . The low-18 $\mathrm{O}$ igneous rocks all lie within an area of propylitic alteration (i.e., an epidotechlorite-actinolite zone) outlined by Peck et al. [1964] on their geologic reconnaissance map of the Western Cascades. This area of propylitic alteration is roughly centered on the South Umpqua River intrusives.

Bohemia mining district. A considerable number of oxygen isotope data have been obtained on rocks and minerals in the vicinity of the Bohemia mining district. The $\delta^{18} O$ values are plotted on a generalized geologic map in Figure 4. The geology of this area has been described in detail by Buddington and Callaghan [1936], Callaghan and Buddington [1938], and by Lutton [1962]. The pile of volcanic country rocks in this locality is about 3500 meters thick, principally tuffs and andesites of the Little Butte volcanic series [Peck et al., 1964]. Two small stocks less than $3 \mathrm{~km}$ in diameter are present, the Champion Creek stock and the Brice Creek stock, together with a large number of much smaller dikes and plugs. The smaller bodies are typically porphyritic augite quartz diorites or dacite porphyries, but the larger stocks are principally mediumgrained, equigranular augite granodiorite. The augites in all these rock types are generally partly altered to fibrous green amphibole, and to a lesser extent to chlorite and epidote.

A well-defined 300 to 600 meter-wide contact metamorphic aureole surrounds the larger stocks (see Figure 4). The most intense metamorphic effects are represented by a tourmaline hornfels, which consists of black masses of tourmaline, 0.1 to $2 \mathrm{~cm}$ in diameter, in a dense, white groundmass of microcrystalline quartz. Other rock types found in the aureole are epidote-tourmaline-

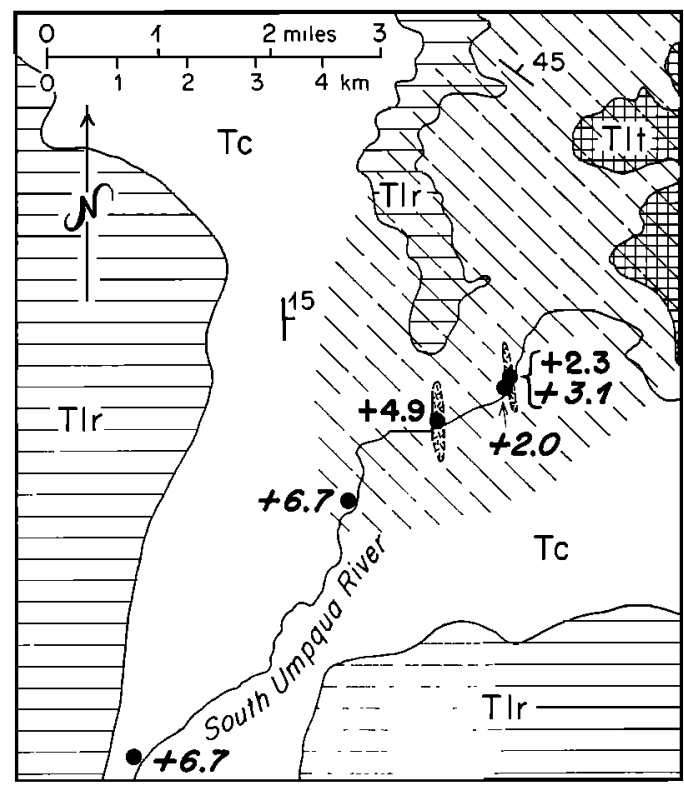

Fig. 3. Generalized geologic map of the South Umpqua River area [after Peck et al., 1964], showing sample localities and whole-rock $\delta^{18} O$ values obtained in the present study. The italicized numbers represent data on volcanic country rocks or xenoliths, and the other numbers represent data on the intrusive igneous rocks. The diagonal dashed pattern indicates the general area of propylitic alteration. Tc, Colestin formation (largely andesite); Tlt and TIr, andesitic to rhyodacitic tuffs of the Little Butte volcanic series. 


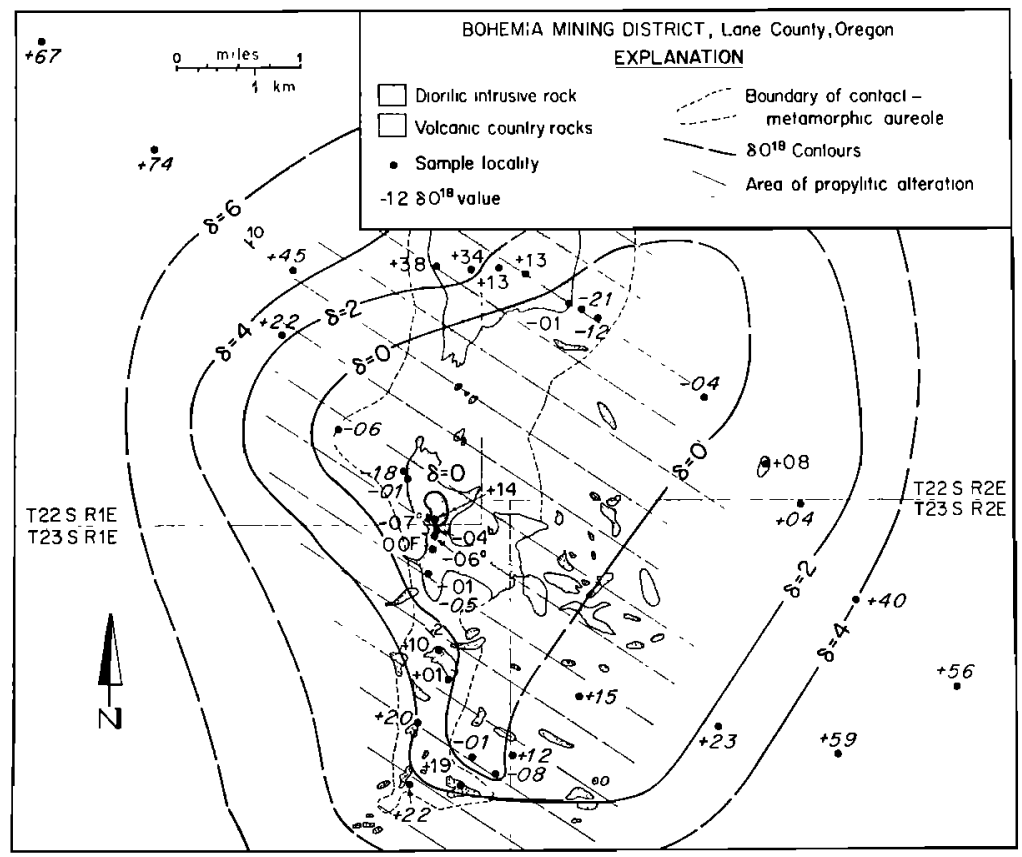

Fig. 4. Generalized geologic map of the Bohemia mining district [after Callaghan and Buddington, 1938; and Lutton, 1962], showing sample localities and whole-rock $\delta^{18} \mathrm{O}$ data. The large stock at the top of the figure is the Brice Creek stock; the somewhat smaller body in the center is the Champion Creek stock. The italicized numbers represent data on volcanic country rocks or xenoliths (andesite and basalt flows and dacite tuffs of the Little Butte volcanic series); the other numbers represent data on the whole-rock samples of the intrusives except that $\delta=0.0 \mathrm{~F}$ in the Champion Creek stock refers to an analysis of an oligoclase feldspar. More detailed ${ }^{18} \mathrm{O} /{ }^{16} \mathrm{O}$ analyses were made on 3 samples near the center of the Champion Creek stock. A $\delta^{18} \mathrm{O}$ value of +1.8 was obtained on a 0.5 -cm-wide, fine-grained, quartz-feldspar-epidote vein cutting one sample $\left(\delta=-0.6^{a}\right)$. A $\delta^{18} \mathrm{O}$ value of +2.8 was obtained on quartz from an epidote-bearing vein in the granodiorite that has a whole-rock $\delta=-0.4^{b}$. The $\delta^{18} \mathrm{O}$ values of coexisting quartz, oligoclase, and actinolite from another sample $\left(\delta=-0.7^{\circ}\right)$ are given in Table 1. Two samples of volcanic rocks collected 1.5 and 2.0 miles downstream (northwest) from the sample locality $(\delta=+6.7$ ) in the upper left corner of the map have $\delta^{18} \mathrm{O}$ values of +7.5 and +7.1 , respectively.

chlorite-magnetite-sericite-(pyrite) hornfels and tourmaline-specularite-sericite hornfels. The outer part of the aureole grades into a zone of propylitic alteration (shown by the diagonal dashed pattern on Figure 4), termed an epidote-chlorite(magnetite, pyrite) hornfels by Buddington and Callaghan [1936]. The mineralogy of the propylitic zone is described by Peck et al. [1964, p. 41].

Sufficient oxygen isotope data have been accumulated on this area to allow us to draw approximate $\delta^{18} \mathrm{O}$ contours for the rocks as shown in Figure 4. Note that the $\delta^{18} \mathrm{O}$ contour pattern is very systematic and approximately coincides with the pattern of propylitic alteration outlined by Peck et al. [1964]. All the rocks collected more than $5 \mathrm{~km}$ distant from the
Champion stock have essentially normal $\delta^{18} O$ values greater than +5.5 . This includes two samples that lie to the NW of the map area shown in Figure 4. Thus in this locality an appreciable outcrop area, including both intrusives and country rocks, exhibits a $\delta^{18} \mathrm{O}$ lower than +2 per mil; the rocks in this area all must have been lowered in $\delta^{18} \mathrm{O}$ by at least 4 per mil. The average $\delta^{18} \mathrm{O}$ value of 19 samples of the altered volcanic country rock is +0.7. A central zone, approximately $5 \mathrm{~km}^{2}$ in area, can be defined in which essentially all rock types have a $\delta^{18} \mathrm{O}$ less than zero. The axis of this central zone is displaced somewhat asymmetrically to the east of the axis of the two major stocks. This asymmetry is most clear cut for the Brice Creek stock, but it 
also seems to be a feature of the Champion Creek body.

The apparent asymmetry of the $\delta^{18} \mathrm{O}$ pattern conceivably is due to the greater abundance of intrusive bodies to the east of the two large stocks than to the west; such an outcrop pattern might indicate the presence of a larger intrusive body at depth. Note that even though the over-all $\delta^{18} \mathrm{O}$ pattern is clearly geographically related to the granodiorite and diorite intrusives, except for the central parts of the two large stocks, it seems to make little difference whether a sample is from an intrusive body or from the volcanic country rocks. This in itself suggests that much or all of the $\delta^{18} \mathrm{O}$ lowering occurred after crystallization of the intrusive bodies.

Of the intrusive bodies, only the Champion Creek stock has been sampled in any detail. It is relatively uniform in $\delta^{18} \mathrm{O}$, with $\delta=-0.7$ to 0.0 throughout, except for a single sample near the center of the body with $\delta^{18} \mathrm{O}=+1.4$. A metamorphosed inclusion of country rock from an agmatite zone near the southern contact is slightly lower in ${ }^{18} \mathrm{O}$ than the host granodiorite $(-0.5$ versus -0.1$)$. Two late-stage epidotebearing veins that cut the granodiorite are slightly enriched in ${ }^{18} \mathrm{O}$ relative to the granodiorite itself. This is consistent with a lowertemperature origin for the veins, because if we assume that the hydrothermal fluids had a constant $\delta^{18} \mathrm{O}$, a given mineral in equilibrium with these fluids would have a higher $\delta^{18} \mathrm{O}$ value, the lower the temperature. If we assume that the quartz in the granodiorite $\left(\delta_{\text {quar } t z}=+0.6\right.$ in the sample with superscript $C$, Figure 4 ) was in exchange equilibrium with $\mathrm{H}_{2} \mathrm{O}$ at $600^{\circ} \mathrm{C}$, the $\delta \mathrm{H}_{2} \mathrm{O}$ would be -1.4 . The quartz from the epidote vein $(\delta=+2.8)$ could have crystallized from an aqueous fluid with $\delta^{18} \mathrm{O}=-1.4$ at a temperature of $445^{\circ} \mathrm{C}$ (based on the quartz-water isotopic geothermometer of Clayton, $\mathrm{O}^{\prime}$ Neil, and Mayeda [O'Neil and Taylor, 1967]).

In the one granodiorite sample in which coexisting minerals were analyzed (superscript $C$ ), the quartz, feldspar, and uralite are clearly not in exact isotopic equilibrium (Table 1, compare with data of Taylor and Epstein [1962]). However, this mineral assemblage does not exhibit the profound isotopic disequilibrium typical of low- ${ }^{-18} \mathrm{O}$ granites from Scotland where quartz-feldspar $\Delta$ values of +4 to +8 are common [Taylor, 1968; Taylor and Forester,
1971]. It is not certain why the quartz from the Champion Creek granodiorite should be depleted in ${ }^{18} \mathrm{O}$ to about the same extent as the coexisting feldspar; it could be because this quartz is much finer grained than in the Scottish granites, or it could imply either that the granodiorite magma itself became ${ }^{18} \mathrm{O}$-depleted or that the stock underwent complete recrystallization in the presence of the $l \mathrm{w}^{-18} \mathrm{O}$ fluids. Grain size clearly must play an important role during interactions between rocks and hot aqueous fluids. This may be the reason why the finegrained inclusion referred to above is lower in 180 than the host granodiorite.

Nimrod stock. The Nimrod stock on the McKenzie River is the largest single intrusive body in the Western Cascades (Figure 5). It is also compositionally unique in that it is principally a fine-grained, leucocratic, biotite quartz monzonite [Buddington and Callaghan, 1936, Figure 5, p. 433]. Subhedral oligoclase is rimmed, veined, and replaced by interstitial, highly turbid $\mathrm{K}$ feldspar. Biotite is the most important mafic mineral, and is typically partially altered to chlorite; locally, however, hornblende is the dominant mafic mineral. Epidote and sericite are rare but ubiquitous alteration products, and small miarolitic cavities lined with epidote are also present.

The $\delta^{18} \mathrm{O}$ data obtained on rocks from the Nimrod area are shown in Figure 5. The Nimrod stock has not been mapped in detail, and the outline shown in Figure 5 is only approximate. The total thickness and general lithology of the flat-lying pile of volcanic country rocks are similar to the situation at the Bohemia mining district. The Nimrod pluton is isotopically quite distinct from its surrounding volcanic country rocks. Except for one sample near the west, contact with $\delta^{18} \mathrm{O}=+0.1$ (in which the mafic minerals are completely altered to actinolite, chlorite, and epidote), the whole-rock $\delta^{18} \mathrm{O}$ values in the stock are all greater than +2.0 . The three most centrally located samples have $\delta^{18} \mathrm{O}=$ $+2.8,+3.6$, and +5.5. The two former samples, from the same locality, are relatively unaltered hornblende granite, whereas the latter is a very fresh biotite quartz monzonite. There is, however, only a rough correlation between the $\delta^{18} \mathrm{O}$ and the degree of alteration of the mafic minerals, because the sample with $\delta=+2.1$ also contains exceedingly fresh, primary biotite $(\delta=-0.8)$, 
TABLE 1. Comparison of ${ }^{18} \mathrm{O} /{ }^{16} \mathrm{O}$ Analyses of Coexisting Minerals* from Low-19 ${ }^{19} \mathrm{O}$ Intrusive Bodies in the Western Cascade Range and the Inner Hebrides, Scotland, with Data on Some Isotopically 'Normal' Plutonic Granitic Rocks from the United States

\begin{tabular}{|c|c|c|c|c|c|}
\hline Sample & $\delta_{\mathrm{qtz}}$ & $\delta_{\text {feld }}$ & $\delta_{\mathrm{amph}}$ & $\Delta_{\mathrm{q} \text { tz-feld }}$ & $\Delta_{\text {feld-amph }}$ \\
\hline \multicolumn{6}{|l|}{ Oregon } \\
\hline \multicolumn{6}{|l|}{ Laurel Hill granodiorite } \\
\hline$\left(\delta_{\mathrm{w}} \mathrm{r}=+0.1\right)$ & +2.0 & -0.1 & -1.8 & 2.1 & 1.7 \\
\hline $\begin{array}{l}\text { Big Cliff Dam diorite porphyry } \\
\left(\delta_{\mathrm{y}}=-0.3\right)\end{array}$ & & & & & \\
\hline $\begin{array}{c}\left(\delta_{\mathrm{w} \cdot \mathrm{r} .}=-0.3\right) \\
\text { Detroit Reservoir granodiorite }\end{array}$ & & +0.5 & -3.0 & & 3.5 \\
\hline$\left(\delta_{\mathrm{w}, r}=0.0\right)$ & +1.9 & +0.2 & -2.2 & 1.7 & 2.4 \\
\hline $\begin{array}{l}\text { Champion Creek granodiorite } \\
\left(\delta_{0}=-0.7\right)\end{array}$ & & $0-5$ & 11 & & 00 \\
\hline $\begin{array}{l}\left(\delta_{\mathrm{w}, \mathrm{r}}=-0.7\right) \\
\text { Nimrod granite }\left(\delta_{\mathrm{w}, \mathrm{r} .}=+2.8\right)\end{array}$ & $\begin{array}{l}+0.0 \\
+6.8\end{array}$ & $+1.3 \dagger$ & -1.4 & $\begin{array}{l}1.1 \\
5.5+\end{array}$ & 0.9 \\
\hline Nimrod granite $\left(\delta_{\mathrm{w} . \mathrm{I} .}=+2.1\right)$ & +4.9 & +1.1 & $-0.8 \ddagger$ & 3.8 & \\
\hline \multicolumn{6}{|l|}{ Scotland § } \\
\hline Ardnamurchan granophyre & -6.0 & $-6.5 \dagger$ & & $0.5 \dagger$ & \\
\hline Mull granophyre & +3.3 & -0.8 & & $4.1^{\circ}$ & \\
\hline Creag Strollamus granite, Skye & +1.0 & -3.1 & & 4.1 & \\
\hline Loch Ainort granite, Skye & +2.9 & -0.5 & & 3.4 & \\
\hline Red Hills granite, Skye & +4.5 & -0.7 & & 5.2 & \\
\hline $\begin{array}{l}\text { Maol na Gainmhich granite, } \\
\text { Skye }\end{array}$ & +5.6 & & & 11.2 & \\
\hline \multicolumn{6}{|l|}{ 'Normal' plutonic granitic rocks } \\
\hline Shake Flat quartz monzonite & +10.3 & +8.9 & +6.4 & 1.4 & 2.5 \\
\hline Alta granodiorite & +9.7 & +8.0 & +5.5 & 1.7 & 2.5 \\
\hline Rubidoux leucogranite & +9.9 & +8.8 & +6.2 & 1.1 & 2.6 \\
\hline Bonsall tonalite & +10.3 & +8.5 & +6.9 & 1.8 & 1.6 \\
\hline San Jose tonalite & +9.7 & +8.0 & +6.6 & 1.7 & 1.4 \\
\hline
\end{tabular}

* qtz, quartz; feld, feldspar; amph, amphibole; w.r., whole rock.

$\dagger$ Calculated from whole-rock $\delta^{18} \mathrm{O}$ value by material balance.

$\ddagger$ Biotite $\delta^{18} \mathrm{O}$ value.

$\S$ Data from Taylor [1968] and Taylor and Forester [1971].

II Data from Taylor and Epstein [1962] and Taylor [1968]. All are rocks from the Southern California and Sierra Nevada batholiths, except the Alta stock, Wasatch Range, Utah.

whereas, in the sample with $\delta=+2.3$, the biotite is completely destroyed and replaced by iddingsite, chlorite, magnetite, and epidote. A fine-grained xenolith of volcanic country rock from the latter locality is even lower in ${ }^{18} \mathrm{O}$, with $\delta=-0.2$. This isotopic difference is somewhat larger, but is in the same direction as that described above for a xenolith from the Champion Creek stock; again, the much finer grain size and lower quartz content of the xenolith may have rendered it more susceptible to isotopic exchange.

All the analyzed volcanic country rocks surrounding the Nimrod stock are considerably lower in ${ }^{18} \mathrm{O}$ than the stock itself, with $\delta=+0.6$ to -5.6 . These samples come from the propylitically altered zone that envelops the stock and extends approximately $15 \mathrm{~km}$ to the northeast.
As one moves out of this altered zone to the east, the $\delta^{18} \mathrm{O}$ values apparently start to go up (i.e., to $\delta=+3.0$ ), but two samples 1.5 to $3 \mathrm{~km}$ west of the pluton, near the western edge of the zone of propylitic alteration mapped by Peck et al. [1964], have lower $\delta$ values $(-5.6,-4.6)$ than any samples yet found in the entire Western Cascades. Both of these samples come from outcrops where there has been a very massive development of epidote (and chlorite) in segregations and veins. Thus, this is one example where the degree of ${ }^{18} \mathrm{O}$ depletion correlates very well with the development of the mineralogical and textural features connected with the hydrothermal alteration. The 'anomalously' low $\delta^{18} \mathrm{O}$ values might be a result of (1) the presence of another intrusive body at a shallow depth directly underlying these localities (e.g., see 
Figure 9), or (2) simply to the vagaries of the 'plumbing system,' whereby these particular rocks happen to be near a major conduit or fracture system and thus have suffered a greater degree of exchange with a larger volume of the meteoric-hydrothermal fluids.

The propylitic alteration zone that extends NE of the Nimrod stock covers an area of about $250 \mathrm{~km}^{2}$ [Peck et al., 1964]. Nine samples of volcanic rocks collected from this area have an average whole-rock $\delta^{18} \mathrm{O}$ of -1.3 . If we assume that these effects originally extended over a vertical distance of $1.5 \mathrm{~km}$, this implies that about $400 \mathrm{~km}^{3}$ of rock must have undergone an over-all ${ }^{18} \mathrm{O}$ depletion of at least 6 or 7 per mil. The average $\delta^{18} \mathrm{O}$ of the Nimrod stock is about 4 per mil higher than in these altered volcanics, but this does not necessarily imply that the stock has suffered a smaller ${ }^{18} \mathrm{O}$ depletion. Calculation of the amount of $\delta^{18} \mathrm{O}$-lowering suffered by a granitic pluton is difficult because fresh, unaltered granitic rocks throughout the world show a greater primary $\delta^{18} \mathrm{O}$ variation than do basalts and andesites. If the Nimrod pluton initially had $\delta^{18} \mathrm{O}=+8.5$ to +9.5 (typical values for a quartz monzonite [Taylor, 1968]), it also must have undergone an over-all ${ }^{18} \mathrm{O}$ depletion of about 6 to 7 per mil, as its average $\delta^{18} \mathrm{O}$ is +2.7 . The central zone, however, would have been lowered by only about 4 per mil, and so, by any model one chooses, the degree of ${ }^{18} \mathrm{O}$ depletion appears to progressively increase westward from the center of the stock.

Vida intrusive body. Two samples were analyzed from a small diorite body at Vida, $11 \mathrm{~km}$ west (downstream) from the Nimrod stock (see Figure 1). These samples are much less depleted in ${ }^{18} \mathrm{O}$ than the Nimrod samples $(\delta=+4.6$, +4.3 ), in keeping with the much smaller size of the Vida intrusive. Thus, this locality is more analogous to the South Umpqua River occurrence in having a higher $\delta^{18} \mathrm{O}$, smaller intrusive bodies, and much smaller area of propylitic alteration.

Detroit Reservoir. Compared with the localities discussed above, the ${ }^{18} \mathrm{O} /{ }^{16} \mathrm{O}$ data from the Detroit Reservoir area (Figure 6) do not show

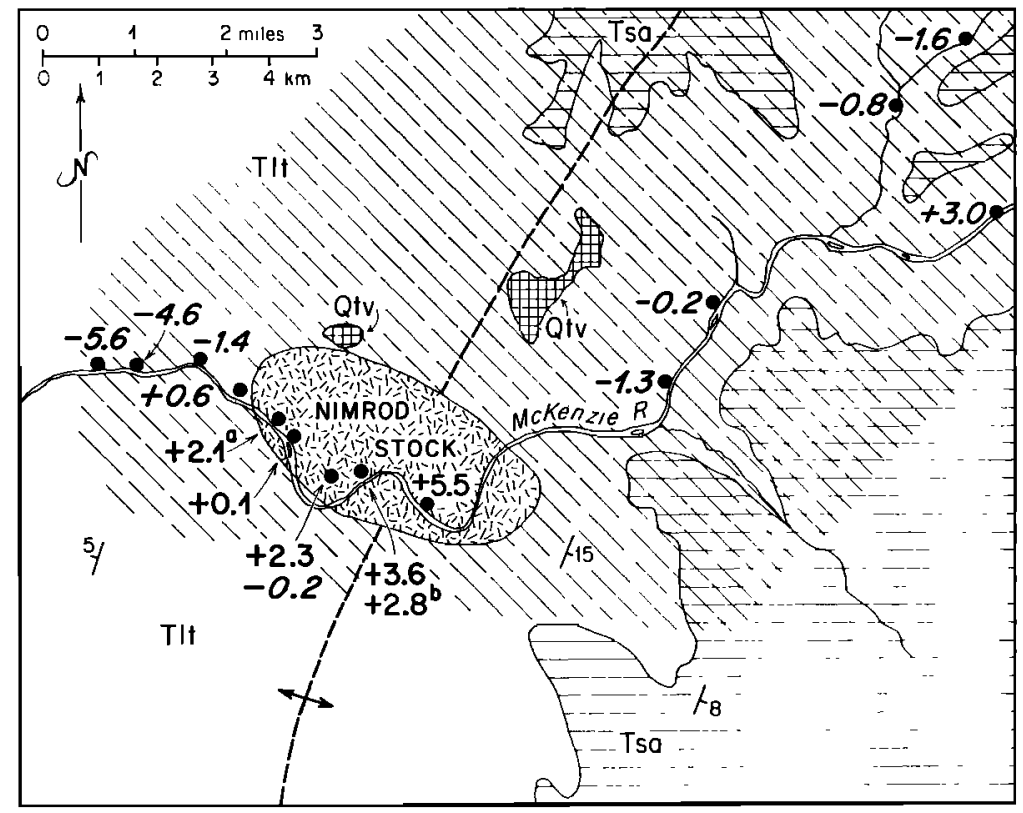

Fig. 5. Generalized geologic map of the area surrounding the Nimrod stock on the McKenzie River [after Peck et al., 1964], showing sample localities and whole-rock $\delta^{18} \mathrm{O}$ data obtained in the present study. Tsa, Sardine formation (largely andesites); Qtv, Pliocene to Quaternary andesites and basalts; other notation similar to that in Figures 3 and $4 .{ }^{18} \mathrm{O} /{ }^{16} \mathrm{O}$ ratios of coexisting minerals from two samples of the Nimrod granite $\left(\delta=+2.1^{a}\right.$ and $\left.+2.8^{b}\right)$ are given in Table $1 . \delta^{18} \mathrm{O}=$ +0.3 was obtained on a diorite inclusion in a small breccia dike $15 \mathrm{~km}$ due east of the Nimrod stock. 


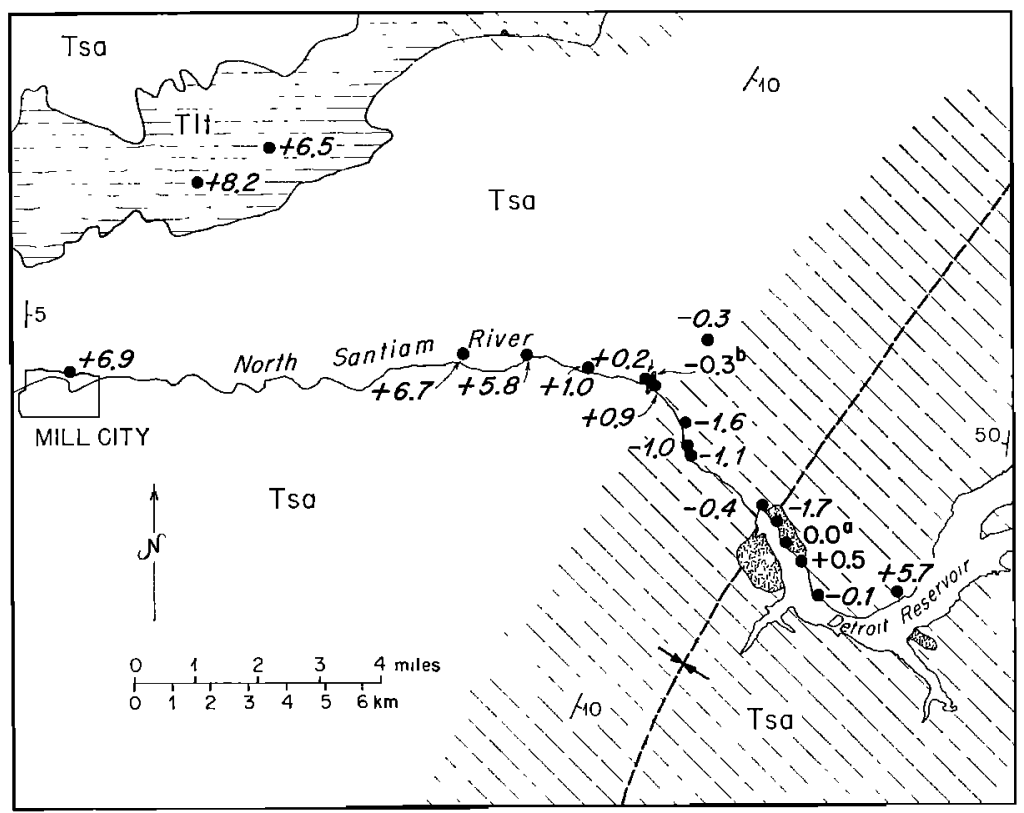

Fig. 6. Generalized geologic map of the Mill City-Detroit Reservoir area [after Peck et al., 1964], showing sample localities and whole-rock $\delta^{18} \mathrm{O}$ data obtained in the present study. The notation is similar to that in Figures 3,4 , and $5 .{ }^{18} \mathrm{O} /{ }^{16} \mathrm{O}$ analyses of coexisting minerals from samples of the Detroit Reservoir granodiorite $\left(\delta=0.0^{a}\right)$ and the Big Cliff Dam diorite porphyry $\left(\delta=-0.3^{b}\right)$ are given in Table 1.

such a good correlation with the area of propylitic alteration mapped by Peck et al. [1964]. In large part, this may be because the geology is much more complicated than is shown on Figure 6, but it should also be remarked that, on the basis of petrographic studies in this work, the western boundary of propylitic alteration should be extended at least $2 \mathrm{~km}$ farther down the North Santiam River. In addition, in the easternmost part of Figure 6 the rocks just to the north of the Detroit Reservoir are only weakly altered. The area of interest is centered on the Sardine syncline, and this area thus represents by far the thickest pile of volcanic rocks of any area studied in the present work. There are at least $\mathbf{5 5 0 0}$ meters of volcanics, capped by andesites of the Miocene Sardine formation [Peck et al., 1964].

Two samples of porphyritic granodiorite were analyzed from the stock at the west end of the Detroit Reservoir, one from near the center of the pluton $(\delta=0.0)$ and one collected 3 meters inward from the east contact $(\delta=+0.5)$; the latter contact is steep and very sharp. In addition, a metavolcanic screen within the mapped confines of the pluton has $\delta^{18} \mathrm{O}=-1.7$. The central granodiorite sample contains oligoclase phenocrysts $(\delta=+0.2)$ embedded in a matrix of interstitial fine-grained turbid alkali feldspar and quartz $(\delta=+1.9)$, much of it in micrographic intergrowths. Actinolitic amphibole $(\delta=$ -2.2) is the only important mafic mineral present. Chlorite and epidote are minor accessories. This area thus appears to be somewhat analogous to the Bohemia mining district in the size, complexity, and nature of the granodiorite intrusives present, and also in the fact that the $\delta^{18} \mathrm{O}$ values of the intrusives and the surrounding country rocks are almost indistinguishable. It does differ, however, in that the isotopically analyzed traverse shown in Figure 6 represents only a very small part of a much larger area of propylitic alteration that extends more than $15 \mathrm{~km}$ to the NE and about $30 \mathrm{~km}$ to the $\mathrm{SW}$ of the Detroit Reservoir [Peck et al., 1964, and Figure 1].

Another, much smaller intrusive body was sampled at Big Cliff Dam about $5 \mathrm{~km} \mathrm{NW}$ of the Detroit stock. This diorite porphyry is intensely altered to epidote and chlorite, contains 
andesine phenocrysts $(\delta=+0.5)$ and actinolite $(\delta=-3.0)$, and has a whole-rock $\delta^{18} \mathrm{O}=-0.3$, slightly lower than in the immediately adjacent volcanic country rocks. All the volcanic rocks between the Detroit granodiorite and the Big Cliff diorite porphyry have negative $\delta^{18} \mathrm{O}$ values, ranging from -0.4 to -1.6 . About $3 \mathrm{~km}$ west of the Big Cliff body, however, the $\delta^{18} \mathrm{O}$ values of the volcanics attain essentially 'normal' values of +5.8 , and from there on west the $\delta$ values are all 'normal' (see Figure 6).

The average whole-rock $\delta$ value of all the samples shown in the eastern half of Figure 6 is $\delta=+0.1$. If this characterizes the entire 50-km-long area of propylitic alteration, a terrane at least $500 \mathrm{~km}^{2}$ in extent must have undergone an over-all ${ }^{18} \mathrm{O}$ depletion of about 6 per mil.

Laurel Hill stock, Mt. Hood area. The Laurel Hill stock, studied by Wise [1969], may not properly belong to the intrusive belt of the Western Cascades, but it is included here because it exhibits the textural and mineralogical characteristics already described. This stock, about $2.5 \mathrm{~km}^{2}$ in area, lies just SW of Mt. Hood and is in fact partially covered by Mt. Hood volcanics (Figure 7). It was emplaced in the
Pliocene, approximately $7 \mathrm{~m} . \mathrm{y}$. ago [Wise, 1969], and is thus probably considerably younger than the other intrusives of the Western Cascades. The stock is principally made up of porphyritic granodiorite and quartz monzonite, but known variants include quartz diorite and granophyre. Actinolite and turbid $K$ feldspar are present throughout, and chlorite and epidote are generally present in minor amount.

The oxygen isotope data are shown in Figure 7. Note that the two samples lowest in ${ }^{18} \mathrm{O}$ (both with $\delta=-2.1$ ) were collected near the margins of the stock, whereas the more centrally located specimen is more than 2 per mil heavier. However, another sample near the western margin has $\delta=+0.7$, so the ${ }^{18} \mathrm{O}$ distribution is not a simple function of position within the intrusion. Considering the relatively small amount of alteration that the stock has undergone, the $\delta^{18} O$ values are remarkably low. In fact, the two samples with $\delta^{18} \mathrm{O}=-2.1$ represent the most ${ }^{18} \mathrm{O}$-depleted intrusive samples yet found anywhere in Oregon. We can only speculate as to why this should be so, but two features are worth considering: (1) The stock may in fact be appreciably larger than is indicated by its outcrop pattern on Figure 7. Wise [1969] believes

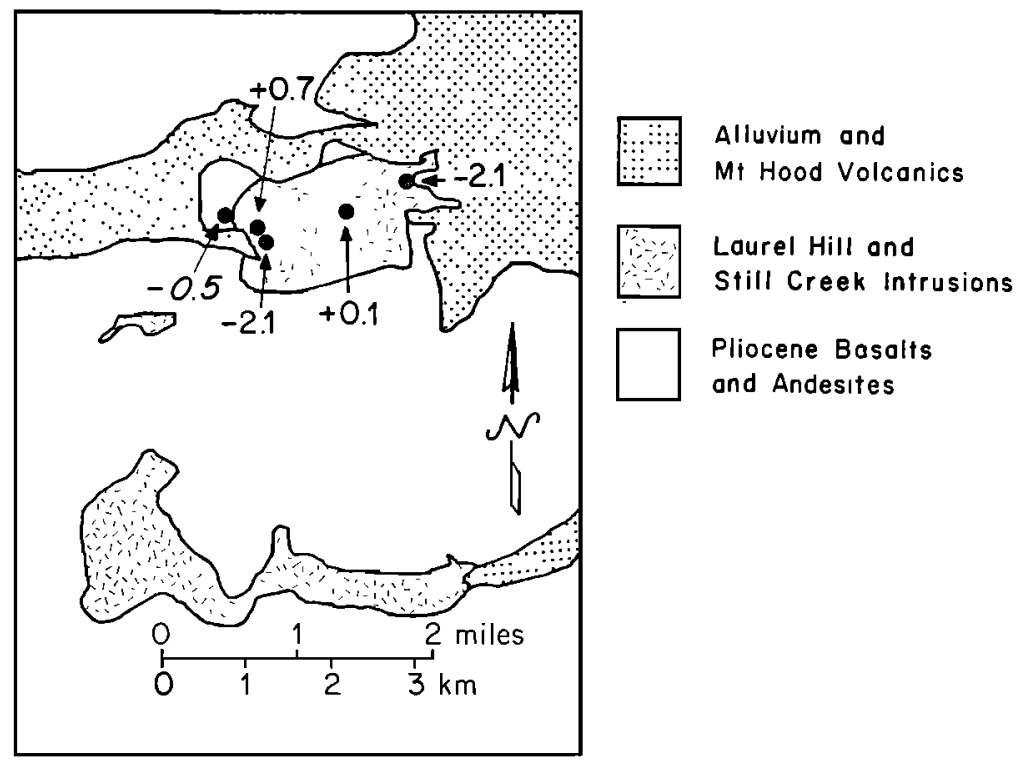

Fig. 7. Generalized geologic map of the Laurel Hill and Still Creek stocks [after Wise, 1969], showing sample localities and whole-rock $\delta^{18} \mathrm{O}$ data obtained in the present study. ${ }^{18} \mathrm{O} /{ }^{16} \mathrm{O}$ data on coexisting minerals in a sample from the center of the Laurel Hill stock $(\delta=+0.1)$ are given in Table 1. 
the Laurel Hill stock to be connected at depth to the elongate Still Creek stock shown at the bottom of Figure 7; if it is, this intrusive body would be the largest of its kind in the Cascades, considerably larger than the Nimrod stock. It might therefore have had a correspondingly larger effect on the meteoric hydrothermal convection pattern in the surrounding country rocks. (2) The Laurel Hill stock presently outcrops at a higher elevation and lies farther north than any of the intrusives described above. Both situations would favor ground waters of lower ${ }^{18} \mathrm{O}$ content, because the $\delta^{18} \mathrm{O}$ of rain and snow tends to decrease with both increasing elevation and latitude [Epstein and Mayeda, 1953; Friedman et al., 1964; Craig, 1961]. Also, the climate in the Pliocene may have been cooler than in the Miocene; this also would tend to produce surface waters of lower ${ }^{18} \mathrm{O}$ content.

Shellrock intrusion, Columbia River. The intrusive body at Shellrock Mountain on the Columbia River (see Figure 1) cuts the Miocene Columbia River basalt and also may not properly belong to the Western Cascade intrusive belt. This porphyritic augite-hypersthene diorite is much less altered than the plutons described above, all the minerals being fresh except the hypersthene, which is partly replaced by uralite. Two whole-rock samples of this body were analyzed for ${ }^{18} \mathrm{O}$, one of which is essentially normal $(\delta=+5.5)$ and the other only slightly depleted $(\delta=+2.9)$. These relatively high $\delta^{18} \mathrm{O}$ values are in keeping with the general absence of hydrothermal alteration effects in this body.

${ }^{18} O$ Fractionations among coexisting minerals. Only a few sets of coexisting minerals were analyzed for ${ }^{18} \mathrm{O}$ in the present study, as is shown in Table 1. The analyses of the granodiorites are remarkable, however, in their similarity. The quartz, feldspar, and actinolitic amphibole from a sample of Champion Creek granodiorite, Laurel Hill granodiorite, and Detroit Reservoir granodiorite each have very similar $\delta^{18} \mathrm{O}$ values. This is somewhat coincidental, since the 3 samples chosen just happen to have similar whole-rock $\delta^{18} \mathrm{O}$ values. Nonetheless, the isotopic similarities, together with the fact that the measured values of $\Delta_{\text {qtz-feld }}$ and $\Delta_{\text {feld-amph }}$ are similar to values obtained on 'normal' igneous rocks [Taylor and Epstein, 1962; Taylor, 1968], all indicate that these assemblages recrystallized in near isotopic equilibrium.

The Nimrod quartz monzonite exhibits values of $\Delta_{\text {qtz-reld }}(3.8,5.5)$ that are much larger than those observed in the Oregon granodiorites (Table 1). These data clearly indicate nonattainment of isotopic equilibrium, and imply that the feldspar continued to exchange with the low-18O hydrothermal fluids even after the ${ }^{18} \mathrm{O} /{ }^{16} \mathrm{O}$ ratios of the coexisting quartz was essentially 'frozen in.' Note that these abnormally large $\Delta$ values in the Nimrod granite also go hand in hand with whole-rock $\delta^{18} \mathrm{O}$ values that are larger than in other intrusive rocks from Oregon. Even though there has over-all been markedly less ${ }^{18} \mathrm{O}$ depletion in the Nimrod granite, the $\delta^{18} \mathrm{O}$ lowering of the Nimrod feldspars must have been similar to that of the granodiorite feldspars shown in Table 1.

\section{Conclusions}

Comparison with other areas of low-180 igneous rocks. The close approach to isotopic equilibrium exhibited by coexisting minerals in the granodiorites from Oregon is not commonly found in other rocks that are known to have suffered intense meteoric-hydrothermal alteration. In Table 1, the Oregon data can be compared with analogous data from some granitic intrusions from Skye, Mull, and Ardnamurchan [Taylor, 1968; Taylor and Forester, 1971]. In the latter samples we commonly observe $\Delta_{\text {qt } z \text {-feld }}$ fractionations of 4 to 10 per mil. This clearly represents a nonequilibrium situation produced because the feldspar exchanged much more extensively with the low ${ }^{18} \mathrm{O}$ fluids than did the quartz. In addition, it is not uncommon to observe $\delta^{18} \mathrm{O}$ values of -4 to -6 in the intrusive igneous rocks of the Hebrides, whereas in Oregon the only intrusive whole-rock $\delta^{18} \mathrm{O}$ values less than -1 are found in the Laurel Hill stock.

What are the reasons for the discrepancies between the Oregon rocks and the Scottish rocks? More work is needed, but the following features are suggested for consideration in subsequent detailed studies:

1. The most likely explanation of the differences in $\Delta$ values is that the finer-grained nature of the quartz in the Oregon rocks (much of it as micropegmatite) made it more susceptible to exchange. Quartz is much less abundant in these quartz diorites and granodiorites than in 
the quartz-bearing Scottish intrusives, most of which are true granites in which the quartz is much coarser grained. Also, in certain instances, very fine-grained micropegmatite quartz from Scotland has also been exchanged down to very low $\delta^{18} \mathrm{O}$ values, as is shown by the data on an Ardnamurchan granophyre given in Table 1. The most conclusive evidence on this point, however, is given by the large values of $\Delta_{\text {qt z-feld }}$ from the Nimrod granite. This body contains quartz that is both coarser grained and more abundant than in any of the granodiorites listed in Table 1, and the quartz-feldspar fractionations of 3.8 to 5.5 are similar to those observed in several granites from Skye and Mull.

2. The Oregon magmas conceivably might have undergone a more pronounced ${ }^{18} \mathrm{O}$ depletion before solidification than the Scottish ring intrusions, and they almost certainly were involved in a much less complicated intrusive history. In the Scottish Hebrides there was a long period of successive igneous intrusion, alternating with explosive volcanic activity, that probably involved a complex overlapping of meteoric-hydrothermal convection systems; this would favor non-equilibrium phenomena.

3. The hydrothermal fluids in Scotland and Oregon may have differed chemically. For example, Taylor and Forester [1971] suggest that $\mathrm{Pb}$ and $\mathrm{Sr}$ isotopic compositions of the Skye rocks may have been drastically affected by the meteoric hydrothermal activity. This in turn suggests that the Scottish hydrothermal solutions were carrying various materials in solution, perhaps abundant $\mathrm{NaCl}, \mathrm{KCl}, \mathrm{CaCl}_{2}$, etc. Such alkali-chloride solutions have an enormously greater potential of exchanging ${ }^{18} \mathrm{O}$ and cations with feldspars than does relatively pure $\mathrm{H}_{2} \mathrm{O}$. $O$ 'Neil and Taylor [1967] have shown that, during cation exchange with feldspars in hydrothermal solutions, the oxygen isotopes are always exchanged as well. In almost all cases, the Skye and Mull feldspars and whole rocks have undergone a greater over-all depletion in ${ }^{18} \mathrm{O}$ than have their counterparts in Oregon. All of these considerations suggest that in Oregon we may be dealing with meteoric-hydrothermal solutions that have not picked up appreciable alkali chlorides in solution, and thus that the effect of differential exchange in coexisting feldspar and quartz is much less pronounced. This is reasonable in terms of the geology also, because the ground waters at Skye and Mull certainly penetrated the Mesozoic and Precambrian sandstone sections, as well as the overlying plateau lavas, whereas, at the present levels of exposure in Oregon, they have only passed through volcanics. It is probable that the former are a much more likely source of saline solutions (evaporites and/or ancient brine) than the latter. The only chemical constituents that definitely seem to have been carried by the meteorichydrothermal solutions in the Oregon intrusive belt are the boron and fluorine necessary to explain the widespread tourmalinization, for example, in the Bohemia mining district [Buddington and Callaghan, 1936]. The volcanics and the intrusives are probably an adequate source of $B$ and F. It will be interesting to check these ideas further by looking at the compositions of fluid inclusions in minerals from the respective areas.

4. There is evidence that in Oregon we are dealing with much broader hydrothermal alteration systems than those that surrounded the Scottish intrusions. If the oxygen isotopic effects are spread out over a much larger volume of country rock, we might a priori expect that, other things being equal, the over-all ${ }^{18} \mathrm{O}$ depletion would have to be correspondingly weaker.

Although the 3-dimensional shapes of the Oregon stocks are not very well known, if we were to make the assumption that like the Scottish intrusions they are roughly cylindrical with steep or near-vertical contacts, the ${ }^{18} \mathrm{O}$ depleted zones surrounding the Oregon intrusives are truly remarkable in their areal extent (Figure 1). This is well shown in Figure 8, where the whole-rock $\delta^{18} \mathrm{O}$ results are plotted as a function of distance from the intrusive contact. In order to take into account the fact that the larger intrusions should in general be surrounded by correspondingly larger meteoric-hydrothermal convection systems, the distances are plotted in units of stock diameter. Note that the $10{ }^{1}{ }^{18} \mathrm{O}$ country-rock zones in the Oregon localities extend outward at least 2.5 to 3.0 stock diameters away from the intrusive contact. However, in Scotland the meager data available suggest that these effects are confined to within about 0.5 'stock' diameter [Taylor and Forester, 1971]. The numbers for Scotland are perhaps somewhat misleading, because the diameters of the Scottish 'stocks' are assumed to be those of an entire 


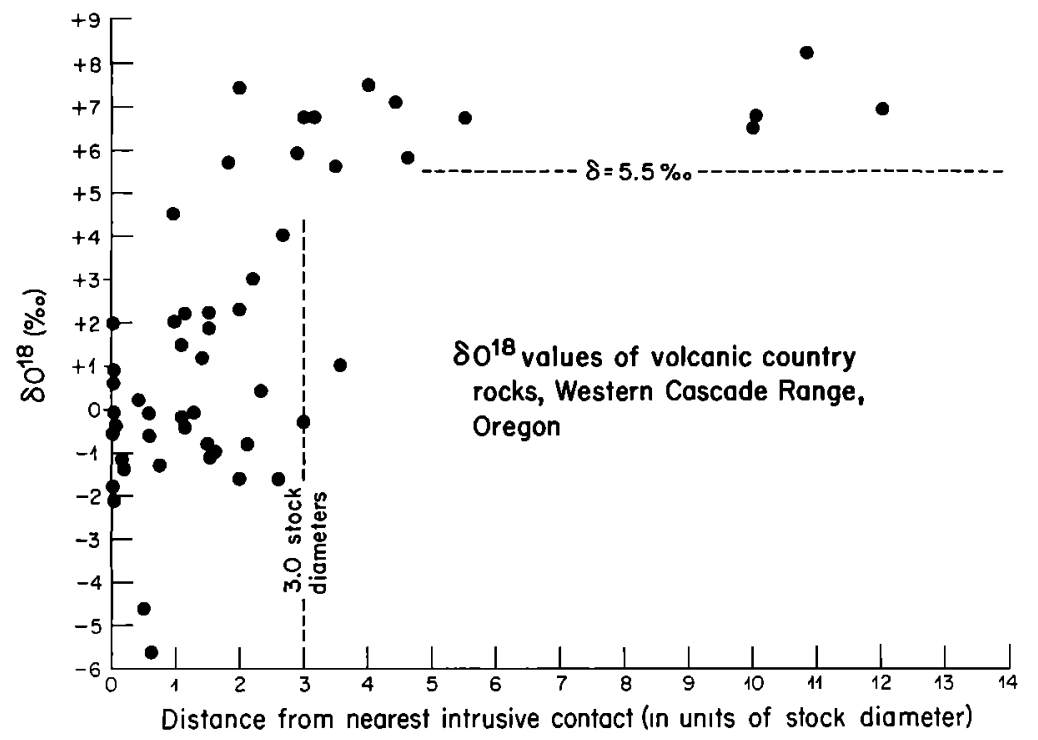

Fig. 8. Plot of whole-rock $\delta^{18} \mathrm{O}$ values of volcanic country rocks from the Western Cascade Range versus distance from the closest intrusive contact (in units of stock diameter). At distances greater than 3.0 stock diameters, the $\delta^{18} \mathrm{O}$ values are essentially 'normal.'

plutonic complex rather than any single intrusion within the complex. However, even if we consider only the diameter of a single igneous center rather than the entire complex, the ${ }^{10 w}{ }^{-18} \mathrm{O}$ aureoles in Oregon are much broader, particularly the ones surrounding the Nimrod and Detroit localities (Figure 1).

We can only speculate as to the reason for these differences in the relative sizes of the aureoles in the two regions. Obviously, a possible effect of importance is the one pointed out above, namely, that the Scottish plutonic centers are largely composed of a number of small ring intrusions emplaced in succession over a long interval of time. Thus at any one point in time the accompanying meteoric-hydrothermal system might also be relatively small. Superposition of many such small systems over an extended period of intrusive activity would explain two features of the isotope data: (a) the relatively smaller areal extent of the low-18 $\mathrm{O}$ aureoles in Scotland, and $(b)$ the fact that even though they are relatively smaller in size, the actual magnitude of the $\delta^{18} \mathrm{O}$ depletion (particularly in feldspars) is much greater in Scotland.

Another feasible explanation of the data is that the present outcrop areas of the Oregon intrusions only represent the eroded tops of large, broad intrusions with relatively gentle, outward- dipping upper contacts. That this is actually the case for the Champion Creek stock (see Figure 4) is suggested by the myriad small intrusions to the east of the stock and the indication that the eastern contact dips gently eastward, roughly concordant with the surrounding strata [Buddington and Callaghan, 1936, p. 426]. Also, the Detroit Reservoir stock (Figure 6) has an essentially flat upper contact at about 600 meters altitude [Peck et al., 1964, p. 39].

$A$ possible model of the meteoric-hydrothermal alteration system. Several aspects of meteorichydrothermal alteration systems associated with epizonal igneous intrusions have been discussed by Sheppard et al. [1969] and Taylor and Forester [1971] and will not be repeated here. However, some of the unique features exhibited by the Oregon bodies are worth considering. A hypothetical composite stock that incorporates most of these features is shown in vertical cross section in Figure 9. The stock acts as a gigantic 'heat engine' that produces a complex pattern of convective circulation in the adjacent local ground waters.

The composite stock shown in Figure 9 was constructed as follows:

$a$. The stock is shown with irregular, outwarddipping contacts in part for the reasons given in paragraph 4 above. Almost all the intrusives in 
the Western Cascades are associated with numerous, small satellitic dikes and plugs, which are probably offshoots of the larger pluton. The clearest evidence favoring this concept, however, is given by a simple heat-balance calculation. If the propylitically altered zone is considered to have been produced by an average rise in the temperature of the country rocks of only about $200^{\circ} \mathrm{C}$ (e.g., from about $50^{\circ} \mathrm{C}$ to $250^{\circ} \mathrm{C}$ ), then with a specific heat of $0.25 \mathrm{cal} / \mathrm{g}$, approximately $50 \mathrm{cal} / \mathrm{g}$ of heat must be added throughout the propylitically altered zones. If we assume a cylindrical magma body initially entirely liquid at a temperature of $950^{\circ} \mathrm{C}$, the maximum amount of heat that can be obtained during crystallization and cooling to $400^{\circ} \mathrm{C}$ is only $220 \mathrm{cal} / \mathrm{g}$ (this includes about $80 \mathrm{cal} / \mathrm{g}$ to take into account the latent heat of crystallization). Thus a cylindrical stock only contains enough heat to produce an alteration aureole at most about 0.6 to 0.7 stock diameters wide, even ignoring the amounts necessary to heat the large volumes of ground water. This calculation is compatible with what is actually observed in the Scottish Hebrides intrusions, but it is totally at odds with the Oregon data. Therefore, the Oregon intrusions either broaden considerably with depth, as indicated in Figure 9, or the propylitic alteration zones are underlain by numerous igneous intrusions that do not outcrop at the present erosion level.

$b$. In light of the above considerations, it is perhaps reasonable that, the greater the outcrop area of an intrusive body, the greater the depth of emplacement of that part of the body. This would mean that the Nimrod pluton would represent the most deeply eroded pluton and the South Umpqua River intrusions the least deeply eroded. It was on this basis that the various horizontal sections were constructed

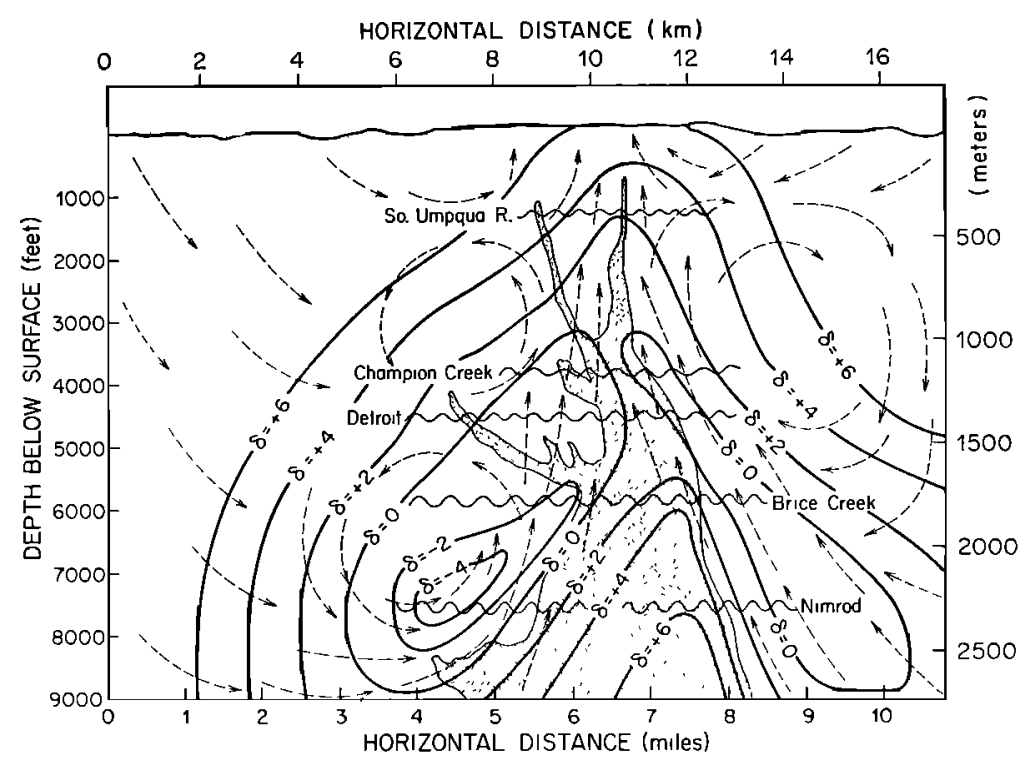

Fig. 9. A vertical cross section through a composite hypothetical granodiorite stock in the Western Cascade Range. The depths below the land surface are only rough estimates, but the horizontal distances have been scaled off the maps in Figures 3, 4, 5, and 6. The horizontal wavy lines indicate approximate east-west sections (looking north) through the South Umpqua River, Detroit, and Nimrod localities, and approximate SE-NW sections (looking SW) through the Brice Creek and Champion Creek stocks in the Bohemia Mining District. The whole-rock $\delta^{18} \mathrm{O}$ data on Figures 3, 4, 5, and 6 have been transformed into a series of $\delta^{18} \mathrm{O}$ contours to indicate the varying degrees of ${ }^{18} \mathrm{O}$ depletion suffered by rocks in the vicinity of the stock. Arrows indicate the radial inward flow of ground waters toward the intrusive stock, the rise of the heated, low-density $\mathrm{H}_{2} \mathrm{O}$, and plausible convective circulations of these fluids through the margins of the stock and in the adjacent volcanic country rocks. Certain stratigraphic units in the volcanic pile are probably much more permeable than others. These 'aquifers' might largely control theconvective circulation. 
through the composite stock shown in Figure 9. In support of the arrangement shown in Figure 9, we also note that: (1) The Nimrod stock presently crops out at the lowest elevation of any of the intrusive bodies, only 275 meters above sea level, in the middle of one of the largest and most deeply dissected canyons in the Western Cascade Range. (2) The Brice Creek and Champion Creek stocks are only $2 \mathrm{~km}$ apart horizontally, but the samples of the former were collected at an altitude of about 700 meters, whereas those of the latter are from an elevation of 900 meters (see Figure 4). (3) The South Umpqua diorite bodies intrude by far the thinnest section of volcanic rocks of any of the localities studied. (4) The Detroit Reservoir and Big Cliff Dam bodies intrude by far the thickest volcanic section, and these bodies presently crop out at altitudes of 450 to 600 meters.

$c$. The relative elevations of the various localities shown on Figure 9 are probably reasonably well placed, but the actual depths assigned are obviously largely guesswork. Nonetheless, the various intrusives have textures and grain sizes that are plausible for the assigned depths. The relatively equigranular, medium-grained granodiorites and granites must have formed at depths of at least 1 or $2 \mathrm{~km}$, particularly when it is remembered that these bodies undoubtedly crystallized abnormally rapidly because of the rapid cooling and heat loss brought about by large-scale interactions with the circulating meteoric ground waters.

$d$. If the general shape and assigned depths of the hypothetical stock shown in Figure 9 are acceptable, the rest of the diagram follows directly from the ${ }^{18} \mathrm{O}$ data shown in Figures 3, 4, 5 , and 6 . The convective circulation of the meteoric ground waters in the vicinity of the stock is only schematic, however, and is probably much more complicated than shown. Note that the volume of altered, ${ }^{18} \mathrm{O}$-depleted country rock is about 30 times as large as the volume of the stock itself, demanding that important quantities of ground water circulate and exchange with a heat source at even greater depths than those shown on Figure 9. The width of the alteration zone obviously cannot continue to increase at a constant rate with depth.

Figure 9 shows that the maximum ${ }^{18} \mathrm{O}$ depletion of the rocks occurs at the stock contact or in the adjacent country rocks. Inasmuch as the volcanic rocks are inherently much more susceptible to isotopic exchange than the stock because of their finer grain size, this does not necessarily mean that less $\mathrm{H}_{2} \mathrm{O}$ moved through the periphery of the stock than through the contact metamorphic aureole. In fact, in the case of the Champion Creek and Detroit stocks, very low $\delta^{18} \mathrm{O}$ values are characteristic of large parts of the intrusive bodies. However, it is also clear from Figure 9 that, as one moves inward into the stock, at some point the relative amounts of $\mathrm{H}_{2} \mathrm{O}$ circulating through the rocks must begin to fall off sharply. The relatively high $\delta^{18} \mathrm{O}$ values in the central parts of the Champion Creek, Brice Creek, and Nimrod stocks are clear evidence of this effect.

The most probable explanation of the above phenomenon is that the hydrothermal convection system begins operating in the country rocks immediately upon intrusion (and perhaps reaches its maximum importance at this time), whereas as long as the stock is partly molten, no fractures or joints can form and thus no convective circulation of $\mathrm{H}_{2} \mathrm{O}$ can be set up inside the body. By the time the center of the stock has solidified enough to fracture, the 'heat engine' is itself much smaller and the convection system is beginning to turn itself off. Also, as a result of mineral deposition along the hydrothermal conduits, many of the routes of access for the aqueous fluids are partially sealed off by this time.

It goes without saying that heat-flow calculations that only involve solutions of the simple heat conduction equation [e.g., Jaeger, 1961] are totally useless in this type of environment. Essentially all the heat is removed through heating and convection of the circulating ground waters.

On the basis of many $\mathrm{D} / \mathrm{H}$ and ${ }^{18} \mathrm{O} /{ }^{16} \mathrm{O}$ analyses of modern geothermal waters from a variety of areas, Harmon Craig has shown that all hotspring waters are at least $95 \%$ of surface derivation [e.g., White, 1968]. Thus the model shown in Figure 9 may apply equally as well to many present meteoric-hydrothermal systems. One of the major difficulties in interpreting such systems has been the problem of heat transfer between the heat source (i.e., the intrusion) and the $\mathrm{H}_{2} \mathrm{O}$. This is generally shown as occurring by simple heat conduction [White, 1968, Figure 3]. On the basis of the data in the present study, the heattransfer problem can probably be adequately 
explained by migration of the $\mathrm{H}_{2} \mathrm{O}$ directly into the heat source itself. The heat exchange thereby occurs through intimate physical contact between the $\mathrm{H}_{2} \mathrm{O}$ and the igneous intrusion.

As well as direct heat and ${ }^{18} \mathrm{O}$ exchange with the solidified intrusive body, some diffusion of meteoric $\mathrm{H}_{2} \mathrm{O}$ into the magma undoubtedly takes place. The augite diorite and granodiorite magmas in the Western Cascades were undoubtedly undersaturated in $\mathrm{H}_{2} \mathrm{O}$ at the time of intrusion and would thus act as a 'sink' for any mobile $\mathrm{H}_{2} \mathrm{O}$ available in the local environment. This would produce some ${ }^{18} \mathrm{O}$ depletion, but we know that most of the $\delta^{18} \mathrm{O}$ lowering in the Nimrod stock, for example, occurred after crystallization, because the feldspar exchanged much more extensively with the aqueous fluids than did coexisting quartz in the same hand specimen (see Table 1).

Amounts of $\mathrm{H}_{2} \mathrm{O}$ involved in the meteorichydrothermal systems. We know the initial $\delta^{18} \mathrm{O}$ values of the volcanic country rocks before hydrothermal alteration with a high degree of accuracy: $+6.5 \pm 1.0$ per mil. However, the initial $\delta^{18} \mathrm{O}$ of the ground waters before heating by the Western Cascades intrusions is more difficult to fix. They almost certainly must have had $\delta^{18} \mathrm{O}$ values between about -5 and -15 , because these are typical for present-day fresh surface waters throughout the world (excluding the arctic regions, oceanic islands, and extremely high elevations). A closer estimate can perhaps be made on the basis of $\mathrm{D} / \mathrm{H}$ analyses of $\mathrm{OH}$ bearing minerals in the Oregon intrusive bodies. H. P. Taylor, Jr., and S. Epstein (unpublished manuscript, 1971) have shown that 4 actinolites and chlorites from these bodies have $\delta \mathrm{D}=-85$ to -100 per mil (relative to SMOW). If we assume a $\delta \mathrm{D}$ fractionation of about 30 per mil between $\mathrm{H}_{2} \mathrm{O}$ and these minerals, which is a reasonable value at $\approx 500^{\circ} \mathrm{C}$ (T. Suzuoki and S. Epstein, unpublished manuscript, 1971), the $\delta \mathrm{D}$ values of these meteoric-hydrothermal waters must have been about -55 to -70 . Inasmuch as enormous amounts of $\mathrm{H}_{2} \mathrm{O}$ are involved, these $\delta \mathrm{D}$ values must also be identical to those of the original, cool ground waters. Using the meteoric water equation

$$
\delta D=8 \delta^{18} \mathrm{O}+10
$$

[Craig, 1961] we obtain estimated initial $\delta^{18} \mathrm{O}$ values of -8 to -10 for these ground waters.
$A$ reasonable choice for the original $\delta^{18} \mathrm{O}$ value of the meteoric ground water is therefore -9 . However, several processes can continuously operate to modify this $\delta$ value before the water enters the hydrothermal exchange system (isotopic exchange with the surrounding rocks, mixing with magmatic or connate waters, etc.). Therefore it is important to consider how much such processes might modify the $\delta^{18} \mathrm{O}$ values of the ground waters.

Marine connate waters initially have $\delta^{18} \mathrm{O} \approx 0$ and primary magmatic waters have $\delta^{18} \mathrm{O} \simeq+6$ to +8 ; thus addition of either type of $\mathrm{H}_{2} \mathrm{O}$ would enrich the ground water in ${ }^{18} \mathrm{O}$. Effects of exchange with the surrounding rocks are more difficult to evaluate because such processes are very sensitive to both temperature and time at temperatures of $50^{\circ}$ to $200^{\circ} \mathrm{C}$. In all subsequent discussions, we shall make the reasonable approximation that $\delta_{\text {rook }}$ and $\delta_{\text {plagioclase (Anao) }}$ are essentially identical at equilibrium so that we can utilize the feldspar-water isotope geothermometer of O'Neil and Taylor [1967]. The applicable equation is then

$$
\delta_{\text {rock }}-\delta_{\mathrm{H}_{2} \mathrm{O}} \approx 2.68\left(10^{6} T^{-2}\right)-3.53
$$

$\left(T\right.$ in $\left.{ }^{\circ} \mathrm{K}\right)$

This means that, at temperatures less than about $100^{\circ} \mathrm{C}$, small amounts of water in exchange equilibrium with isotopically 'normal' volcanic rocks can attain $\delta^{18} \mathrm{O}$ values less than -9 . However, rates of exchange are so low at such temperatures that this is probably not an important process, particularly when large amounts of water are involved.

In light of the above considerations, it is not necessary to consider initial $\delta_{\text {water }}$ values lower than -12 or higher than -3 , and it is felt that a $\delta_{\text {water }} \approx-9$ is by far the most likely. These results are incorporated in Figure 10, where for various values of $\delta_{\text {water }}$ we plot $\delta_{\text {rook }}$ as a function of the water/rock ratio calculated on the basis of the simplest possible closed system model (e.g., Table 2, and Sheppard et al. [1969, p. 770]).

The data in Figure 10 indicate that as a practical matter it is impossible to explain the lowest-18O volcanic rock at Nimrod with a $\delta_{\text {water }}=-6$ much less than with a $\delta_{\text {water }}=-3$. Absurdly high water/rock ratios $(\gg 10)$ would be required, assuming any reasonable temperature lower than $600^{\circ} \mathrm{C}$. Even for $\delta_{\text {water }}=-9$, a 


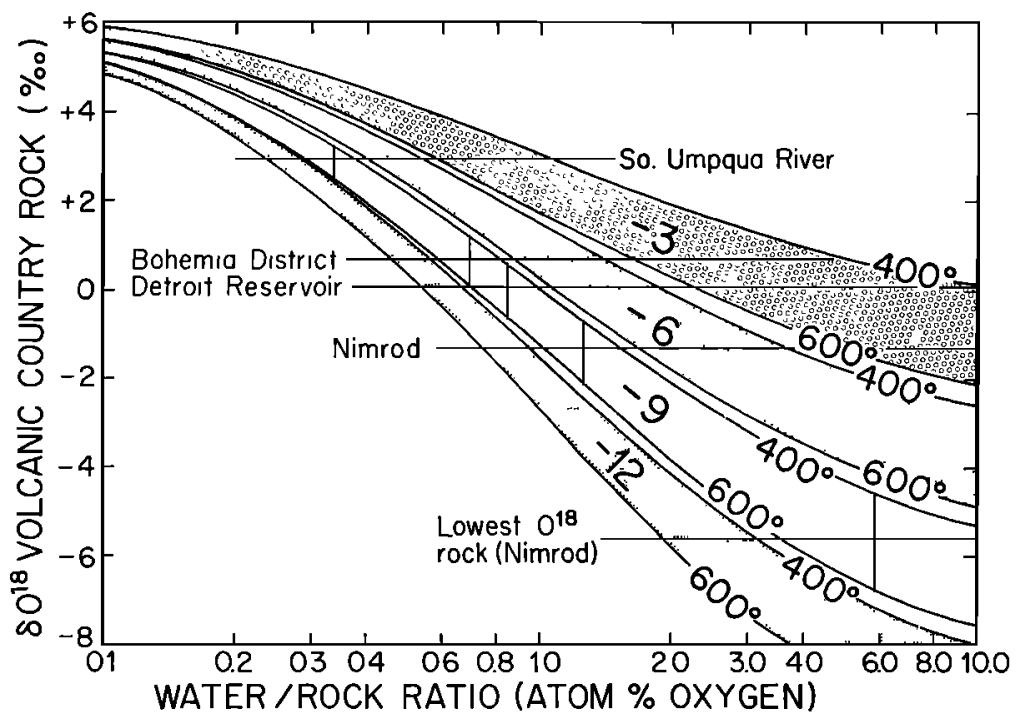

Fig. 10. Plot of whole-rock $\delta^{18} \mathrm{O}$ of the volcanic country rocks of the Western Cascade Range versus the calculated ratio of the amount of meteoric-hydrothermal water to the amount of exchanged, ${ }^{18} \mathrm{O}$-depleted volcanic rock (log scale). It should be remembered that this is an integrated water/rock ratio, in that it refers to the total amount of water that has migrated through and exchanged with the rocks. The 4 diagonal bands represent 4 different $\delta^{18} \mathrm{O}$ values of the initial ground water entering the exchange system $\left(\delta_{\text {water }}=-12,-9,-6\right.$, and -3$)$. The upper and lower limits on each band are calculated on the basis of isotopic equilibrium between rock and water at $400^{\circ} \mathrm{C}$ and $600^{\circ} \mathrm{C}$, respectively. Most of the country rocks in the vicinity of the igneous intrusions were probably heated to such temperatures. However, if a lower temperature of $300^{\circ} \mathrm{C}$ were chosen for a particular band, the upper limit of that band would lie approximately in the middle of the next overlying band, and correspondingly greater amounts of water would thus be necessary to produce a given ${ }^{18} \mathrm{O}$ depletion in a rock. The horizontal lines indicate the average $\delta^{18} \mathrm{O}$ values of the volcanic country rocks in 4 different localities studied in the present work, as well as the $\delta^{18} \mathrm{O}$ value of the most ${ }^{18} \mathrm{O}$-depleted rock found in Oregon (from the Nimrod area). The band for $\delta_{\text {water }}=-9$ is thought to closely approximate conditions in the Western Cascade meteoric-hydrothermal exchange systems, and under these circumstances the average water/rock ratios for the various localities would be given by the crosses in the $\delta_{w a t e r}=-9$ band. If initial $\delta_{\text {water }}$ values of -6 or greater are chosen, it is impossible to explain the low- ${ }^{18} \mathrm{O}$ rock from Nimrod with any reasonable water/rock ratio (i.e., $<10$ ).

relatively high water/rock ratio of about 6.0 is required (Figure 10). Using this $\delta_{\text {water }}$ and the average $\delta^{18} \mathrm{O}$ values of the volcanic country rocks at various localities in the Western Cascades, we obtain the average water/rock ratios shown in Figure 10 and Table 2. It is of interest that the smallest intrusions (South Umpqua River) are associated with the smallest water/rock ratio, whereas the reverse effect is observed for the large Nimrod stock. Figure 10 also clearly demonstrates that the lower the temperature of hydrothermal alteration, the larger the water/ rock ratio necessary to produce a given $\delta_{\text {rock }}$.

Table 3 presents some approximate calculations of the total amounts of $\mathrm{H}_{2} \mathrm{O}$ involved in various meteoric-hydrothermal alteration sys- tems in the Western Cascades. In most of the areas, we must have had interaction between roughly equal amounts of water and rock (expressed as atomic per cent oxygen). Note that about $8 \%$ of the area of the Western Cascades is probably underlain by rocks that have been depleted in ${ }^{18} \mathrm{O}$ by about 5 to 6 per mil; therefore, at least in this region, such low-180 igneous rocks cannot be considered to be uncommon. The development of such large-scale ${ }^{18} \mathrm{O}$ depletion requires a total volume of water of at least $2000 \mathrm{~km}^{3}$. If this water was supplied from a drainage basin $\frac{1}{2}$ the area of the present Western Cascades, and if we assume an annual rainfall of $75 \mathrm{~cm}$ (30 inches), of which only $5 \%$ ultimately is added to the deep ground-water circulation 
TABLE 2. Calculated 'Temperatures' of Isotopic Exchange between $\mathrm{H}_{2} \mathrm{O}$ and the Volcanic Country Rocks, Assuming a Simple Closed-System Model (see text) and Constant Water/Rock Ratios of 0.8 and 1.0

(Under these conditions, the $\delta^{18} \mathrm{O}$ contours in the country rocks in Figures 4 and 9 also represent isotherms)

\begin{tabular}{rcc}
\hline & \multicolumn{2}{c}{ Temperature, ${ }^{\circ} \mathrm{C}$} \\
\cline { 2 - 3 }$\delta_{\text {rock }}$ & $\mathrm{w} / \mathrm{r}=0.8$ & $\mathrm{w} / \mathrm{r}=1.0$ \\
\hline+6 & $115^{\circ}$ & $110^{\circ}$ \\
+5 & $140^{\circ}$ & $135^{\circ}$ \\
+4 & $175^{\circ}$ & $165^{\circ}$ \\
+3 & $215^{\circ}$ & $200^{\circ}$ \\
+2 & $275^{\circ}$ & $245^{\circ}$ \\
+1 & $360^{\circ}$ & $305^{\circ}$ \\
0 & $505^{\circ}$ & $395^{\circ}$ \\
-1 & $845^{\circ}$ & $540^{\circ}$ \\
-2 & $\infty$ & $875^{\circ}$
\end{tabular}

* Calculated assuming that

$$
\delta_{\text {rock }} \approx \delta_{\text {plagioclage }(\mathrm{A} \mathrm{I} \mathrm{aO})} \text {, }
$$

utilizing the following equation:

$$
\frac{\delta_{\text {rock }}-6.5}{-9-\left(\delta_{\text {rock }}-\Delta\right)}=\mathrm{w} / \mathrm{r}=0.8 \text { or } 1.0
$$

where 6.5 is the original $\delta^{18} \mathrm{O}$ of the unaltered volcanic rocks, -9 is assumed to be the original $\delta^{18} \mathrm{O}$ of the meteoric ground waters, and $\Delta$ is the ${ }^{18} \mathrm{O}$ fractionation between rock and water; $\Delta=$ $2.68\left(10^{6} T^{-2}\right)-3.53$, where $T$ is in ${ }^{\circ} \mathrm{K}\left[O^{\prime} N\right.$ eil and Taylor, 1967].

system, it would require only about 7000 years to produce the observed effects. In particular, note that in young volcanic terranes most of the local rainfall quickly migrates down into the jointed rocks, very little moving off immediately as surface runoff.

Obviously the period of intrusion, crystallization, and cooling of the Oregon plutonic bodies extended over a much longer time period than 7000 years. In fact, even today many hot springs are found throughout the Western Cascades, though they generally tend to occur somewhat to the east of the axis of mid-Tertiary intrusions shown in Figure 1.

Temperature gradients in the hydrothermal alteration aureole. It is clear that the inward increase in $\delta^{18} \mathrm{O}$ in the hypothetical stock shown in Figure 9 is due to progressively smaller water/ rock ratios as one moves into the stock. Also, it is in part a result of the fact that by the time the $\mathrm{H}_{2} \mathrm{O}$ gets well into the stock it has already undergone appreciable ${ }^{18} \mathrm{O}$ enrichment through exchange with the heated rocks through which it has passed. It is probably at present impossible to separate these two effects.

The variations in $\delta{ }^{18} \mathrm{O}$ in the volcanic country rocks are perhaps more amenable to analysis. The outward increase in $\delta^{18} \mathrm{O}$ in the propylitically altered zones cannot, of course, be due to the water having been abnormally enriched in ${ }^{18} \mathrm{O}$ due to exchange. Just the reverse would be expected. There is, however, probably a tendency for somewhat larger water/rock ratios to be found in the vicinity of the stock margins. First, at temperatures below $100^{\circ} \mathrm{C}$ the effective water/rock ratio is very small, because isotopic exchange rates are so much slower. Second, because of radial inward migration of water toward the igneous intrusion, the water/rock ratio would be expected to progressively increase toward the stock because, assuming cylindrical geometry, the rock volume decreases inward as the square of the distance. However, throughout the zones of upward streaming or convective circulation, the water/rock ratio should be roughly constant.

If the water/rock ratio is in fact roughly constant throughout an appreciable volume of rock, the $\delta^{18} \mathrm{O}$ contours in the rocks should also represent approximate isotherms, as is indicated in Table 2 for two different water/rock ratios, 0.8 and 1.0. Thus the increase in $\delta^{18} \mathrm{O}$ outward from the stock would be principally due to falling temperatures as one moves away from the heat source. In the region between the contours $\delta_{\text {rock }}=+6$ and +4 , where the water/ rock ratio is likely to be relatively smaller, it can be shown that the calculated temperatures are not strongly dependent on the water/rock ratio. For example, at $\delta_{\text {rock }}=+4$, the calculated 'temperatures' are $235^{\circ} \mathrm{C}$ and $195^{\circ} \mathrm{C}$, respectively, for water/rock ratios of 0.4 and 0.6 (compare with data in Table 2). For $\delta_{\text {rock }}>+4$, the temperature differences are practically negligible.

It is probably going to be difficult to directly apply oxygen isotope geothermometry to coexisting minerals in the propylitic alteration zones because of the general lack of attainment of isotopic equilibrium (see Table 1). Therefore, we must have recourse to indirect methods like those shown in Table 2. In fact, however, for a water/rock ratio of 0.8 or 1.0 (which from 
Figure 9 and Table 3 seem to be typical values in the Western Cascades), these indirect methods give very reasonable temperatures. The horizontal temperature gradient outward from the Champion stock (Figure 4) would, on the basis of such a calculation, fall off from about $550^{\circ} \mathrm{C}$ in the periphery of the stock to about $110^{\circ} \mathrm{C}$ at the $\delta=+6$ contour. This corresponds to an average drop of about $100 \% \mathrm{~km}$ to the west and $70^{\circ} / \mathrm{km}$ to the east of the stock, the gradient becoming less steep away from the intrusive body.

Occurrences of low-180 igneous rocks. The data in the present study and that given by Taylor [1968] and Taylor and Forester [1971] indicate that ${ }^{\circ}{ }^{-18} \mathrm{O}$ igneous rocks are nowhere near so rare as was once thought. Areas of at least 1000 $\mathrm{km}^{2}$ in Oregon and $1000 \mathrm{~km}^{2}$ in the Scottish Hebrides are apparently underlain by rocks with $\delta^{18} \mathrm{O}=-6$ to +4 . Very extensive areas of low- ${ }^{18} \mathrm{O}$ rocks also occur in the San Juan Mountains, Colorado (H. P. Taylor and R. W. Forester, unpublished data, 1971). They also have been found in parts of the Boulder batholith (S. M. F. Sheppard and H. P. Taylor, Jr., unpublished manuscript, 1971), the Skaergaard intrusion in Greenland [Taylor and Epstein, 1962], and in the Corona micropegmatite granite of the Southern California batholith (H. P. Taylor, unpublished data, 1971).
All the above occurrences are, however, of Cretaceous or Tertiary age; very little work has been done to try to identify $\operatorname{low}^{-18} \mathrm{O}$ igneous rocks of pre-Cretaceous age. The only definitely known occurrences are single samples of the late Precambrian Seychelles Island granite [Taylor, 1968] and the Mesozoic ring-dike complex in the Ossipee Mountains, New Hampshire (H. P. Taylor, unpublished data, 1971). Inasmuch as we are dealing with phenomena that take place in shallow parts of the earth's crust, it would be expected that because of erosion and burial by younger rocks the older occurrences would be much less common. It is nevertheless very important to search for and identify Precambrian igneous bodies that have interacted with superficial waters, because the $\delta^{18} \mathrm{O}$ and $\delta \mathrm{D}$ values of such waters are determined in large part by the $\delta \mathrm{D}$ and $\delta^{18} \mathrm{O}$ values of the oceans that existed at the time of intrusion. Thus, this may be a way to trace the variation of $\delta^{18} \mathrm{O}$ and $\delta \mathrm{D}$ in ocean waters and rain waters through geologic time. This method could have some great advantages compared with the utilization of sedimentary materials like cherts and carbonates to obtain data on the isotopic evolution of the ancient oceans [e.g., Perry, 1967]. The principal advantage is that one would be dealing with much more coarsely crystalline rocks which have an enormously better chance of preserving

TABLE 3. Data on the Propylitically Altered Areas of the Western Cascade Range, and Calculated Amounts of $\mathrm{H}_{2} \mathrm{O}$ Involved in the Various Meteoric-Hydrothermal Alteration Systems

\begin{tabular}{|c|c|c|c|c|c|c|}
\hline Area & Avg. $\delta^{18} \mathrm{O}$ c.r. ${ }^{*}$ & Area, $\mathrm{km}^{2}$ & $\begin{array}{l}\text { Vertical } \\
\text { Extent, } \\
\text { meters } \dagger\end{array}$ & $\begin{array}{c}\text { Volume of } \\
\text { Altered Rock, } \\
\text { km }^{3}\end{array}$ & $\begin{array}{c}\text { Water/Rock } \\
\text { Ratio } \ddagger\end{array}$ & $\begin{array}{l}\text { Volume of } \\
\mathrm{H}_{2} \mathrm{O}, \mathrm{km}^{3} \S\end{array}$ \\
\hline \multicolumn{7}{|l|}{ South Umpqua } \\
\hline River & +3.0 & 25 & $400-1000$ & $10-25$ & 0.35 & $5-13$ \\
\hline Bohemia district & +0.7 & 75 & $1000-3000$ & $75-225$ & 0.7 & $75-225$ \\
\hline Nimrod & -1.3 & 250 & $1500-3500$ & $375-875$ & 1.2 & $650-1500$ \\
\hline Detroit Reservoir & +0.1 & 500 & $1500-5000$ & $750-2500$ & 0.8 & $900-3000$ \\
\hline \multicolumn{7}{|l|}{ Entire Western } \\
\hline $\begin{array}{l}\text { Cascades } \\
\left(15,000 \mathrm{~km}^{2}\right)\end{array}$ & $\approx 0.0$ & $\approx 1200$ & $\approx 1500-3000$ & $=1800-3600$ & $\approx 0.8$ & $=2000-4500$ \\
\hline
\end{tabular}

* Average $\delta^{18} \mathrm{O}$ of samples of the propylitically altered volcanic country rocks (for the South Umpqua River area, the average includes the $\delta^{18} \mathrm{O}$ analyses of the small intrusive bodies; see Figure 3 ).

$\dagger$ Assumed vertical distance (in meters) over which the $10 \mathrm{w}^{-18} \mathrm{O}$ alteration effects probably extend; this is estimated from the areal extent of the alteration zone and from the thickness of the volcanic pile in the given locality [after Peck at el., 1964].

$\ddagger$ The calculated water/rock ratio (in terms of atomic per cent oxygen) as given in Figure 10, assuming that the $\mathrm{H}_{9} \mathrm{O}$ has an initial $\delta^{18} \mathrm{O}=-9$.

\$ Approximate volume of meteoric ground water involved in each hydrothermal alteration system, assuming the density of the $\mathrm{H}_{2} \mathrm{O}$ is $1.0 \mathrm{~g} / \mathrm{cm}^{3}$. Note that these are minimum values because it was probable that isotopic equilibrium was not invariably attained between the rocks and the $\mathrm{H}_{2} \mathrm{O}$. 
their ${ }^{18} \mathrm{O} /{ }^{16} \mathrm{O}$ (and $\mathrm{D} / \mathrm{H}$ ?) ratios through geologic time. Also, the time coordinate can in theory be exactly fixed, because the original isotopic interaction with ground waters had to occur during crystallization and cooling of the pluton.

Acknowledgments. This research was supported by the National Science Foundation, grant GA12945.

Discussions with A. F. Buddington, R. W. Forester, and D. E. White have been helpful. E. M. Taylor kindly provided two of the samples analyzed in this study, and P. Yanagisawa did much of the laboratory work.

\section{ReFERENCES}

Buddington, A. F., and E. Callaghan, Dioritic intrusive rocks and contact metamorphism in the Cascade Range in Oregon, Amer. J. Sci., 31, 421-449, 1936.

Callaghan, E., and A. F. Buddington, Metalliferous mineral deposits of the Cascade Range in Oregon, U.S. Geol. Surv. Bull., 89s, 141 pp., 1938.

Craig, H., Isotopic variations in meteoric waters, Science, 183, 1702-1703, 1961.

Epstein, S., and T. Mayeda, Variation of ${ }^{18} \mathrm{O}$ content of waters from natural sources, Geochim. Cosmochim. Acta, 4, 213-224, 1953.

Friedman, I., A. C. Redfield, B. Schoen, and J. Harris, The variation of the deuterium content of natural waters in the hydrologic cycle, Rev. Geophys., 2, 177-224, 1964.

Jaeger, J. C., The cooling of irregularly shaped igneous bodies, Amer. J. Sci., 259, 721-734, 1961.

Lutton, R. J., Geology of the Bohemia mining district, Lane County, Oregon, Ph.D. thesis, Univ. of Arizona, 1962.

O'Neil, J. R., and H. P. Taylor, Jr., The oxygen isotope and cation exchange chemistry of feldspars, Amer. Mineral., 52, 1414-1437, 1967.

Peck, D. L., A. B. Griggs, A. G. Schlicker, F. G. Wells, and H. M. Dole, Geology of the central and northern parts of the western Cascade Range in
Oregon, U.S. Geol. Survey Prof. Pap. 449, 56 pp., 1964.

Perry, E. C., The oxygen isotope chemistry of ancient cherts, Earth Planet. Sci. Lett., 3, 62-66, 1967.

Sheppard, S. M. F., R. L. Nielsen, and H. P. Taylor, Jr., Oxygen and hydrogen isotope ratios of clay minerals from porphyry copper deposits, Econ. Geol., 64, 755-777, 1969.

Taylor, H. P., Jr., Oxygen isotope studies of hydrothermal mineral deposits, in Geochemistry of Hydrothermal Ore Deposits, edited by H. L. Barnes, pp. 109-142, Holt, Rinehart, and Winston, New York, 1967.

Taylor, H. P., Jr., The oxygen isotope geochemistry of igneous rocks, Contrib. Mineral. Petrol., 19, $1-71,1968$.

Taylor, H. P., Jr., and S. Epstein, Relationship between $\mathrm{O}^{18} / \mathrm{O}^{16}$ ratios in coexisting minerals of igneous and metamorphic rocks, 1, Principles and experimental results, Bull. Geol. Soc. Amer. 78, 461-486, 1962.

Taylor, H. P , Jr., and S. Epstein, Hydrogen isotope evidence for influx of meteoric ground water into shallow igneous intrusions, Geol. Soc. Amer. Spec. Pap. 121, 294, 1968.

Taylor, H. P., Jr., and R. W. Forester, Low-O $\mathrm{O}^{18}$ igneous rocks from the intrusive complexes of Skye, Mull, and Ardnamurchan, Western Scotland, J. Petrol., in press, 1971.

White, D. E., Hydrology, activity, and heat flow of the Steamboat Springs thermal system, Washoi County, Nevada, U.S. Geol. Surv. Prof. Pap. 458-C, 109 pp., 1968.

Williams, H., Volcanoes of the Three Sisters Region, Oregon Cascades, Univ. Calif. Publ. Geol. Sci., 27, 37-84, 1944.

Wise, W. S, Geology and petrology of the Mt. Hood area: A study of High Cascade volcanism, Geol. Soc. Amer. Bull., 80, 969-1006, 1969.

(Received March 18, 1971; revised June 3, 1971.) 